\title{
Drivers of diel and regional variations of halocarbon emissions from the tropical North East Atlantic
}

\author{
H. Hepach ${ }^{1}$, B. Quack ${ }^{1}$, F. Ziska ${ }^{1}$, S. Fuhlbrügge ${ }^{1}$, E. L. Atlas ${ }^{2}$, K. Krüger ${ }^{1, *}$, I. Peeken ${ }^{3,4}$, and D. W. R. Wallace ${ }^{1, * *}$ \\ ${ }^{1}$ GEOMAR Helmholtz-Zentrum für Ozeanforschung Kiel, Germany \\ ${ }^{2}$ Rosenstiel School of Marine and Atmospheric Science (RSMAS), University of Miami, USA \\ ${ }^{3}$ Alfred-Wegener-Institut für Polar und Meeresforschung (AWI), Bremerhaven, Germany \\ ${ }^{4}$ MARUM - Center for Marine Environmental Sciences, University Bremen, Bremen, Germany \\ * now at: Department of Geosciences, University of Oslo (UiO), Oslo, Norway \\ ** now at: Department of Oceanography, Dalhousie University, Halifax, Canada
}

Correspondence to: H. Hepach (hhepach@geomar.de)

Received: 15 July 2013 - Published in Atmos. Chem. Phys. Discuss.: 25 July 2013

Revised: 9 December 2013 - Accepted: 10 December 2013 - Published: 3 February 2014

\begin{abstract}
Methyl iodide $\left(\mathrm{CH}_{3} \mathrm{I}\right)$, bromoform $\left(\mathrm{CHBr}_{3}\right)$ and dibromomethane $\left(\mathrm{CH}_{2} \mathrm{Br}_{2}\right)$, which are produced naturally in the oceans, take part in ozone chemistry both in the troposphere and the stratosphere. The significance of oceanic upwelling regions for emissions of these trace gases in the global context is still uncertain although they have been identified as important source regions. To better quantify the role of upwelling areas in current and future climate, this paper analyzes major factors that influenced halocarbon emissions from the tropical North East Atlantic including the Mauritanian upwelling during the DRIVE expedition. Diel and regional variability of oceanic and atmospheric $\mathrm{CH}_{3} \mathrm{I}, \mathrm{CHBr}_{3}$ and $\mathrm{CH}_{2} \mathrm{Br}_{2}$ was determined along with biological and physical parameters at six $24 \mathrm{~h}$-stations. Low oceanic concentrations of $\mathrm{CH}_{3}$ I from $0.1-5.4 \mathrm{pmol} \mathrm{L}^{-1}$ were equally distributed throughout the investigation area. $\mathrm{CHBr}_{3}$ and $\mathrm{CH}_{2} \mathrm{Br}_{2}$ from 1.0 to $42.4 \mathrm{pmol} \mathrm{L}^{-1}$ and to $9.4 \mathrm{pmol} \mathrm{L}^{-1}$, respectively were measured with maximum concentrations close to the Mauritanian coast. Atmospheric $\mathrm{CH}_{3} \mathrm{I}, \mathrm{CHBr}_{3}$, and $\mathrm{CH}_{2} \mathrm{Br}_{2}$ of up to $3.3,8.9$, and $3.1 \mathrm{ppt}$, respectively were detected above the upwelling, as well as up to 1.8, 12.8, and $2.2 \mathrm{ppt}$ at the Cape Verdean coast. While diel variability in $\mathrm{CH}_{3} \mathrm{I}$ emissions could be mainly ascribed to oceanic nonbiological production, no main driver was identified for its emissions over the entire study region. In contrast, biological parameters showed the greatest influence on the regional distribution of sea-to-air fluxes of bromocarbons. The diel impact of wind speed on bromocarbon emissions increased
\end{abstract}

with decreasing distance to the coast. The height of the marine atmospheric boundary layer (MABL) influenced halocarbon emissions via its influence on atmospheric mixing ratios. Oceanic and atmospheric halocarbons correlated well in the study region, and in combination with high oceanic $\mathrm{CH}_{3} \mathrm{I}$, $\mathrm{CHBr}_{3}$ and $\mathrm{CH}_{2} \mathrm{Br}_{2}$ concentrations, local hot spots of atmospheric halocarbons could solely be explained by marine sources. This conclusion is in contrast to previous studies that hypothesized elevated atmospheric halocarbons above the eastern tropical Atlantic to be mainly originated from the West-African continent.

\section{Introduction}

Volatile halogenated hydrocarbons (halocarbons) occur naturally in the oceans from where they are emitted into the atmosphere. Bromine and iodine atoms released from these compounds by photolysis and oxidation can take part in catalytic ozone destroying cycles in both the troposphere and stratosphere (McGivern et al., 2000; Salawitch et al., 2005; Montzka and Reimann, 2011) with iodine also participating in aerosol formation (O'Dowd et al., 2002). Halocarbons comprise brominated and iodinated methanes such as bromoform $\left(\mathrm{CHBr}_{3}\right)$ and dibromomethane $\left(\mathrm{CH}_{2} \mathrm{Br}_{2}\right)$, methyl iodide $\left(\mathrm{CH}_{3} \mathrm{I}\right)$ and diiodomethane, as well as longer chained and mixed halogenated compounds such as iodoethane, chloroiodomethane, and dibromochloromethane. 
While $\mathrm{CHBr}_{3}$ and $\mathrm{CH}_{2} \mathrm{Br}_{2}$ represent the largest contributors to atmospheric organic bromine from the ocean to the atmosphere (Hossaini et al., 2012a), methyl iodide $\left(\mathrm{CH}_{3} \mathrm{I}\right)$, originating mostly from marine sources, is the most abundant organoiodine in the atmosphere (Saiz-Lopez et al., 2012). Although these three halocarbons are among those that receive the most attention due to their large contributions to atmospheric organic halogens, many uncertainties remain regarding their formation pathways, influences on their emissions, and their fate in the ocean and the atmosphere.

Elevated halocarbon concentrations, particularly of $\mathrm{CHBr}_{3}$ and $\mathrm{CH}_{2} \mathrm{Br}_{2}$, occur in coastal regions where macro algae are thought to be the most dominant sources (Carpenter and Liss, 2000; Laturnus, 2001). Elevated concentrations of halocarbons are often observed in upwelling regions with large phytoplankton activity, where cold, nutrient rich water is brought up to the sea surface (Tokarczyk and Moore, 1994; Quack et al., 2004). Abiotic production such as photochemical processes could be of high significance for the marine formation of iodinated organic trace gases (Martino et al., 2009), e.g. $\mathrm{CH}_{3} \mathrm{I}$. Hence, its distribution in the ocean may depend on physical parameters such as insolation (Moore and Groszko, 1999; Richter and Wallace, 2004; Yokouchi et al., 2008; Stemmler et al., 2013).

The subtropical and tropical regions represent the largest contributors to global emission budgets of $\mathrm{CH}_{3} \mathrm{I}, \mathrm{CHBr}_{3}$ and $\mathrm{CH}_{2} \mathrm{Br}_{2}$ (Ziska et al., 2013). The compounds and their degradation products can be carried into the stratosphere in significant quantities (Solomon et al., 1994; Hossaini et al., 2010; Aschmann et al., 2011; Montzka and Reimann, 2011; Tegtmeier et al., 2013), since deep tropical convection can lift surface air very rapidly into the tropical tropopause layer (Tegtmeier et al., 2012). Studies by Pyle et al. (2007) and Hossaini et al. (2012b) projected considerable changes in future inorganic bromine in the tropical troposphere and to the stratosphere from biogenic halocarbon emissions due to strengthening of convection, increasing their importance in the tropics. Coastal upwelling systems might play a crucial role in a changing climate. The tropical Mauritanian upwelling is an example of a recently intensified coastal eastern boundary upwelling (McGregor et al., 2007). Primary production could increase with enhanced entrainment of nutrient rich deep water into the surface ocean leading to amplified production of halocarbons. Increasing wind speeds, caused by enhanced pressure gradients (Bakun, 1990), would also directly influence the sea-to-air fluxes of all trace gases via a faster transfer coefficient (e.g. Nightingale et al., 2000). Thus the identification of factors impacting halocarbon sea-to-air fluxes is crucial for assessing possible effects of climate change on future emissions from coastal upwelling systems.

This paper reports on oceanic and atmospheric halocarbon distributions and sea-to-air fluxes from the DRIVE (Diurnal and RegIonal Variability of halogen Emissions) campaign of RV Poseidon in the eastern tropical North Atlantic and the Mauritanian upwelling in June 2010. We present re- sults from six $24 \mathrm{~h}$-stations in different distances from the Mauritanian coast and from two simultaneous diel stations on the Cape Verde island Sao Vincente. We aim at describing and quantifying significant factors that control the concentrations and emission fluxes of $\mathrm{CH}_{3} \mathrm{I}, \mathrm{CHBr}_{3}$, and $\mathrm{CH}_{2} \mathrm{Br}_{2}$ both on a diel and a regional scale, including biological production, wind speed, and atmospheric transport. Previous studies have hypothesized that elevated atmospheric mixing ratios of $\mathrm{CHBr}_{3}$ and $\mathrm{CH}_{2} \mathrm{Br}_{2}$ above the Mauritanian upwelling area were mainly of continental origin, since sea-to-air fluxes of these compounds appeared not sufficient to explain the observations (Quack et al., 2007a; Carpenter et al., 2009). In contrast, the investigation by Fuhlbrügge et al. (2013) revealed high atmospheric mixing ratios of $\mathrm{CH}_{3} \mathrm{I}, \mathrm{CHBr}_{3}$ and $\mathrm{CH}_{2} \mathrm{Br}_{2}$ close to the coast also in air masses transported from the open ocean, with a significant anticorrelation between the atmospheric mixing ratios and the height of MABL. We therefore examine how oceanic emissions contribute to the mixing ratios of atmospheric halocarbons taking the height of the marine atmospheric boundary layer (MABL) into account. Meteorological constraints on the atmospheric distributions during the cruise are investigated in the accompanying paper by Fuhlbrügge et al. (2013).

\section{Methods}

The cruise P399/2 (Poseidon 399 leg 2) named DRIVE (Diurnal and RegIonal Variability of halogen Emissions) of RVPoseidon took place from May 31 to June 17 in 2010 in the eastern tropical North Atlantic and the Mauritanian upwelling. The ship followed a course from Las Palmas (Canary Islands, $28.1^{\circ} \mathrm{N}$ and $15.4^{\circ} \mathrm{W}$ ) back to Las Palmas with a short stop at Mindelo (Sao Vicente, Cape Verde, $16.9^{\circ} \mathrm{N}$ and $\left.25.0^{\circ} \mathrm{W}\right)$. The cruise track included six stations located at $17.6^{\circ} \mathrm{N}$ and $24.3^{\circ} \mathrm{W}(\mathrm{S} 1), 18.0^{\circ} \mathrm{N}$ and $21.0^{\circ} \mathrm{W}(\mathrm{S} 2), 18.0^{\circ} \mathrm{N}$ and $18.0^{\circ} \mathrm{W}(\mathrm{S} 3), 18.5^{\circ} \mathrm{N}$ and $16.5^{\circ} \mathrm{W}(\mathrm{S} 4), 19.0^{\circ} \mathrm{N}$ and $16.6^{\circ} \mathrm{W}$ (S5), and $20.0^{\circ} \mathrm{N}$ and $17.3^{\circ} \mathrm{W}$ (S6) where the ship remained at its position for $24 \mathrm{~h}$ (Fig. 1). Samples for dissolved halocarbons in sea water, atmospheric halocarbons and phytoplankton pigments were taken at all $24 \mathrm{~h}$-stations in parallel, and additionally four radio sonde launches per 24hstation were accomplished to determine the MABL properties. More details on the campaign and the meteorological conditions can be found in Bange et al. (2011) and Fuhlbrügge et al. (2013).

Related to the ship expedition a land-based operation took place from 3 to 8 June 2010 at the Cape Verde Atmospheric Observatory (CVAO) on Sao Vincente close to Mindelo at $17.6^{\circ} \mathrm{N}$ and $24.3^{\circ} \mathrm{W}$ (Fig. 1) where samples of atmospheric halocarbons were taken during two days.

Atmospheric halocarbon mixing ratios and meteorological conditions were also determined during a second cruise leg P399/3 from Las Palmas, Spain to Vigo, Spain and are covered in Fuhlbrügge et al. (2013). In contrast, this manuscript 
focuses only on results from leg P399/2. The words "whole cruise" will refer to leg 2 and "whole campaign" includes leg 2 and the land-based operation at Cape Verde.

\subsection{Sampling and analysis of halocarbons in sea surface water and air}

Dissolved halocarbons were sampled in $500 \mathrm{~mL}$ amber glass bottles from a continuously working pump from the ships moon pool at a depth of $4.4 \mathrm{~m}$. This allowed for nearly hourly sampling of sea surface water at every diel station. In between $24 \mathrm{~h}$-stations, the samples were taken every $3 \mathrm{~h}$. The water was analyzed for halocarbons using a purge and trap system attached to a gas chromatograph with mass spectrometric detection (GC-MS). $80 \mathrm{~mL}$ of water were purged at $70^{\circ} \mathrm{C}$ for $60 \mathrm{~min}$ with a stream of helium at $30 \mathrm{~mL} \mathrm{~min}^{-1}$ in a glass chamber with a purge efficiency of more than $98 \%$ for all three halocarbons. The volatilized trace gases were desiccated with a Nafion ${ }^{\circledR}$ dryer and were trapped on glass beads at $-100^{\circ} \mathrm{C}$. After purging, the compounds were desorbed at $100^{\circ} \mathrm{C}$ onto a deactivated capillary in liquid nitrogen as second trap. After three minutes, the sample was injected into the GC-MS, where the trace gases were separated on a Rtx-VGC capillary column with a length of $60 \mathrm{~m}$, a diameter of $0.25 \mathrm{~mm}$ and a film thickness of $1.40 \mu \mathrm{m}$, and were detected in single ion mode. Quantification was achieved with volumetrically prepared standards in methanol. Four calibration curves were performed using different dilutions, each injected in triplicate. One standard was injected once a day in triplicate to monitor the internal drift of the instrumental set up which was low during the whole cruise. Precision for these measurements lay within $16 \%$ for $\mathrm{CH}_{3} \mathrm{I}$, and $6 \%$ for $\mathrm{CHBr}_{3}$ and $\mathrm{CH}_{2} \mathrm{Br}_{2}$, determined only from duplicates due to time constraints.

Air samples were taken hourly at the diel stations. They were pumped into stainless steel canisters on the compass deck at a height of $13.7 \mathrm{~m}$ with a metal bellows pump. Samples were analyzed within a month at the Rosenstiel School of Marine and Atmospheric Science in Miami with a precision of approximately $5 \%$ using GC-MS (Schauffler et al., 1999). Previous campaigns show that stability of the measured compounds in the canisters is not an issue over this time period. Additionally, air samples were taken at CVAO on an hourly basis parallel to the first two diel stations of the ship. Samples were taken according to the method onboard the RV Poseidon in approximately $3 \mathrm{~m}$ height above ground and then analyzed along with the other canisters collected during the cruise. Oceanic and atmospheric measurements were intercalibrated against whole air working-standards obtained from the NOAA Global Monitoring Division (Boulder, USA).

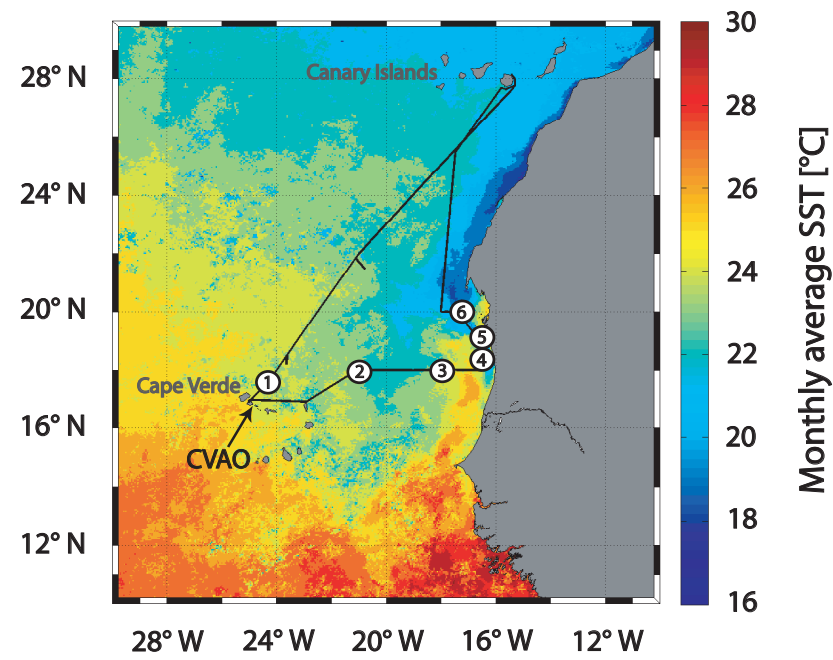

Fig. 1. Cruise track (black line) during DRIVE on SST derived from the monthly composite of June 2010 of MODIS-Aqua level 3 data. White circles with black numbers indicate $24 \mathrm{~h}$-stations. Also marked is the location of the CVAO (Cape Verde Atmospheric Observatory).

\subsection{Phytoplankton pigment analysis and flow cytometry}

Samples for pigment analysis were taken approximately every $2 \mathrm{~h}$ at every diel station. $1 \mathrm{~L}$ of sea surface water from the continuously working pump in the ships moon pool was filtered through $25 \mathrm{~mm}$ Whatman $\mathrm{GF} / \mathrm{F}$ filters and stored at $-80^{\circ} \mathrm{C}$ until analysis. Back in the lab, phytoplankton pigments were analyzed according to Tran et al. (2013) using a Waters high-performance liquid chromatography (HPLC) system at the Alfred Wegener Institute for Polar and Marine Research Bremerhaven (AWI). Apart from chlorophyll $a$ (Chl $a$ ), the 27 marker pigments for which samples were analyzed include various chlorophyll type pigments such as chlorophyll $c 1, c 2$ and $c 3$, divinyl chlorophyll $b$, chlorophyll $b$, divinyl chlorophyll $a$, and phaeophytin $a$. The following carotenoids were detected: peridin, predinin derivative, 19-butanoyloxyfucoxanthin, fucoxanthin, neoxanthin, 19-hexanoyloxyfucoxanthin, violaxanthin, astaxanthin, prasinoxanthin, diadinoxanthin, alloxanthin, diatoxanthin, anthreaxanthin, zeaxanthin, lutein, $\alpha$-carotene, and $\beta$ carotene. Marker pigments and their relative abundance are indicative for different phytoplankton groups.

For flow cytometry, $4 \mathrm{~mL}$ of water from the underway pump system were preserved with glutaraldehyde with a final concentration of $0.1 \%$, shock frozen in liquid nitrogen and stored at $-80^{\circ} \mathrm{C}$. Flow cytometry samples were analyzed for nanoplankton, picoplankton, Prochlorococcus, and Synechococcus at the AWI according to Taylor et al. (2011). Potential cell loss associated with the sample fixation has not been taken into account. 
Table 1. Means and ranges (minimum - maximum) of ambient parameters (SST, salinity, Chl $a$, wind speed, MABL height) during DRIVE for open ocean stations S1-S2 and coastal stations S3-S6.

\begin{tabular}{|c|c|c|c|c|c|c|c|}
\hline & & $\mathrm{S} 1$ & $\mathrm{~S} 2$ & $\mathrm{~S} 3$ & $\mathrm{~S} 4$ & S5 & S6 \\
\hline Parameter & Unit & $\begin{array}{l}17.6^{\circ} \mathrm{N} \text { and } \\
24.3^{\circ} \mathrm{W}\end{array}$ & $\begin{array}{l}18.0^{\circ} \mathrm{N} \text { and } \\
21.0^{\circ} \mathrm{W}\end{array}$ & $\begin{array}{l}18.0^{\circ} \mathrm{N} \text { and } \\
18.0^{\circ} \mathrm{W}\end{array}$ & $\begin{array}{l}18.5^{\circ} \mathrm{N} \text { and } \\
16.5^{\circ} \mathrm{W}\end{array}$ & $\begin{array}{l}19.0^{\circ} \mathrm{N} \text { and } \\
16.6^{\circ} \mathrm{W}\end{array}$ & $\begin{array}{l}20.0^{\circ} \mathrm{N} \text { and } \\
17.3^{\circ} \mathrm{W}\end{array}$ \\
\hline SST & ${ }^{\circ} \mathrm{C}$ & $\begin{array}{l}24.5 \\
(24.4-24.7)\end{array}$ & $\begin{array}{l}23.2 \\
(23.0-23.6)\end{array}$ & $\begin{array}{l}21.7 \\
(21.6-21.8)\end{array}$ & $\begin{array}{l}23.3 \\
(23.1-23.4)\end{array}$ & $\begin{array}{l}20.4 \\
(20.2-21.0)\end{array}$ & $\begin{array}{l}18.6 \\
(18.4-18.7)\end{array}$ \\
\hline Salinity & & $\begin{array}{l}36.7 \\
(36.7-36.7)\end{array}$ & $\begin{array}{l}36.4 \\
(36.4-36.5)\end{array}$ & $\begin{array}{l}35.9 \\
(35.9-35.9)\end{array}$ & $\begin{array}{l}35.9 \\
(35.9-35.9)\end{array}$ & $\begin{array}{l}35.8 \\
(35.8-35.8)\end{array}$ & $\begin{array}{l}35.9 \\
(35.8-35.9)\end{array}$ \\
\hline Chl $a$ & $\mu g \mathrm{~L}^{-1}$ & $\begin{array}{l}0.05 \\
(0-0.08)\end{array}$ & $\begin{array}{l}0.30 \\
(0.10-0.43)\end{array}$ & $\begin{array}{l}1.00 \\
(0.58-1.79)\end{array}$ & $\begin{array}{l}1.63 \\
(0.81-3.01)\end{array}$ & $\begin{array}{l}4.50 \\
(1.69-8.12)\end{array}$ & $\begin{array}{l}4.80 \\
(7.40-6.70)\end{array}$ \\
\hline Wind speed & $\mathrm{ms}^{-1}$ & $\begin{array}{l}4.6 \\
(2.0-7.1)\end{array}$ & $\begin{array}{l}11.0 \\
(7.8-14.8)\end{array}$ & $\begin{array}{l}6.0 \\
(3.9-9.0)\end{array}$ & $\begin{array}{l}9.7 \\
(6.7-12.9)\end{array}$ & $\begin{array}{l}8.9 \\
(4.3-13.7)\end{array}$ & $\begin{array}{l}11.0 \\
(6.8-14.2)\end{array}$ \\
\hline MABL height & $\mathrm{m}$ & $\begin{array}{l}950 \\
(850-1100)\end{array}$ & $\begin{array}{l}540 \\
(400-700)\end{array}$ & $\begin{array}{l}290 \\
(200-400)\end{array}$ & $\begin{array}{l}120 \\
(50-200)\end{array}$ & $\begin{array}{l}25 \\
\text { (surface-100) }\end{array}$ & $\begin{array}{l}190 \\
(100-350)\end{array}$ \\
\hline
\end{tabular}

\subsection{Calculation of sea-to-air fluxes and saturation anomaly}

Sea-to-air fluxes $(F)$ of $\mathrm{CH}_{3} \mathrm{I}, \mathrm{CHBr}_{3}$ and $\mathrm{CH}_{2} \mathrm{Br}_{2}$ were calculated using the air-sea gas exchange parameterization of Nightingale et al. (2000). Schmidt number (Sc) corrections for the compound specific transfer coefficients $k_{\mathrm{W}}$ derived with the transfer coefficient $k_{\mathrm{CO}_{2}}$ of $\mathrm{CO}_{2}$ as reported by Quack and Wallace (2003) were applied.

$\frac{k_{\mathrm{w}}}{k_{\mathrm{CO}_{2}}}=\frac{S c^{-\frac{1}{2}}}{660}$

The air-sea concentration gradient was derived from all simultaneous water $\left(c_{\mathrm{w}}\right)$ and air $\left(c_{\mathrm{atm}}\right)$ measurements calculated with the Henry's law constants $H$ of Moore and coworkers (Moore et al., 1995a, b) to obtain the theoretical equilibrium concentration $c_{\mathrm{atm}} / H$.

$F=k_{\mathrm{w}} \cdot\left(c_{\mathrm{w}}-\frac{c_{\mathrm{atm}}}{H}\right)$

The saturation anomaly $S$ was calculated from the concentration gradient as the percentage of the equilibrium concentration.

$S=\left(\left(c_{\mathrm{w}}-\frac{c_{\mathrm{atm}}}{H}\right) \cdot 100\right) \cdot\left(\frac{c_{\mathrm{atm}}}{H}\right)^{-1}$

Water temperature and salinity were continuously recorded using the ships' thermosalinograph. Air pressure and wind speed were determined by sensors on the compass deck and in $25.5 \mathrm{~m}$ height, respectively. Ten minute averages of these four parameters were included in the calculations, and wind speed was corrected to $10 \mathrm{~m}$ values.

\section{Hydrography and environmental parameters during DRIVE}

High SST values between 23.0 and $24.7^{\circ} \mathrm{C}$ and high salinities from 36.4 to 36.7 observed at $\mathrm{S} 1$ and $\mathrm{S} 2$ close to Cape Verde (Figs. 1-2a, Table 1) were consistent with tropical surface water characteristics (Tsuchiya et al., 1992). Low Chl $a$ concentrations between 0.00 and $0.43 \mu \mathrm{g} \mathrm{L}^{-1}$ were a sign of low primary production there. Stations S1 and S2 are hence defined as open ocean. Wind speed had the lowest mean of the whole cruise at $\mathrm{S} 1$ with $4.6 \mathrm{~m} \mathrm{~s}^{-1}$ and was highest at $\mathrm{S} 2$ with a mean of $11.0 \mathrm{~m} \mathrm{~s}^{-1}$. The MABL height in this region determined by Fuhlbrügge et al. (2013) ranged between 400 and $1100 \mathrm{~m}$ (Table 1). With decreasing distance to the Mauritanian coast, a decrease in SST and salinity and an increase in Chl $a$ concentrations were observed. This is a sign of the North West African upwelling system on the African shelf as part of the wind-driven Canary Current extending from $30^{\circ} \mathrm{N}$ to $10^{\circ} \mathrm{N}$ (Fedoseev, 1970). South Atlantic Central Water (SACW), characterized as a straight T-S curve between $5^{\circ} \mathrm{C}$ and 34.3 and $20^{\circ} \mathrm{C}$ and 36.0 (Tomczak and Godfrey, 2005), is transported to the Mauritanian coast by a poleward directed undercurrent. Between $12^{\circ} \mathrm{N}$ and $20^{\circ} \mathrm{N}$ upwelling of the cold nutrient rich SACW takes place from late fall to late spring (Minas et al., 1982; Tomczak, 1982; Hagen, 2001) after which the upwelling starts to cease due to changing atmospheric conditions induced by the shift of the Intertropical Convergence Zone (Mittelstaedt, 1982). Although the upwelling already began to cease during our cruise, stations S3-S6 are defined as upwelling and coastal stations (further on called coastal stations) due to the lower SSTs observed there. The lowest SST with $18.4^{\circ} \mathrm{C}$ as well as the highest daily mean $\mathrm{Chl} a$ concentration of $4.80 \mu \mathrm{g} \mathrm{L}^{-1}$ were found at the northernmost station (S6), while the overall maximum Chl $a$ concentration of $8.12 \mu \mathrm{g} \mathrm{L}^{-1}$ was observed at S5. MABL heights generally ranged between surface and $400 \mathrm{~m}$ 
(1) (2) (3) (4) (5) (6)

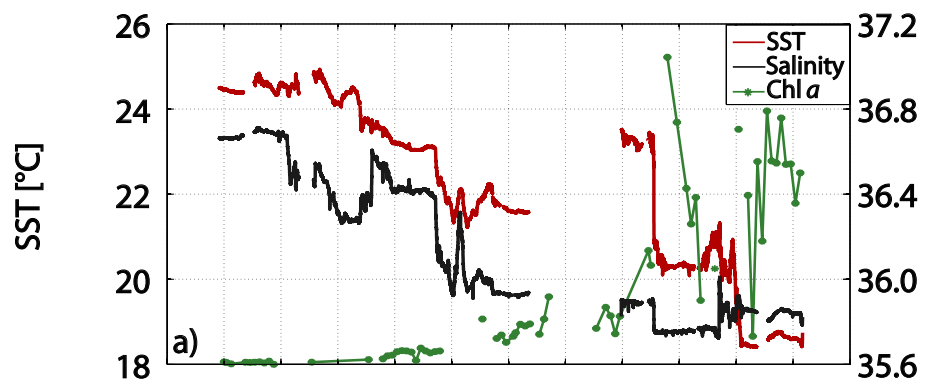

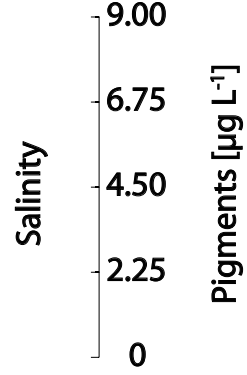

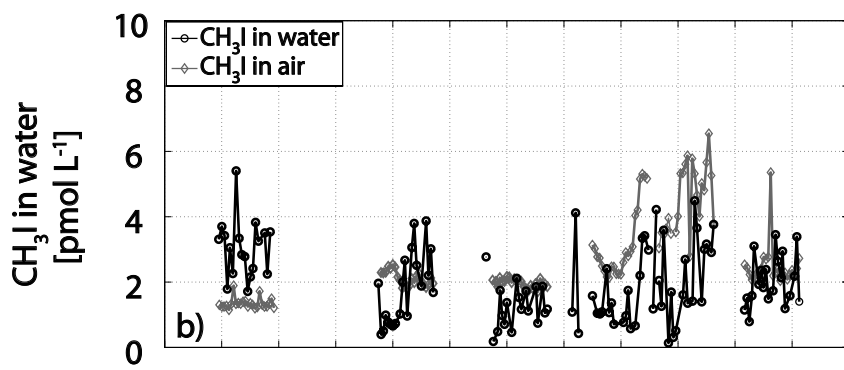

5

4 宽

3 는

$2 \stackrel{\cong}{\stackrel{\Xi}{I^{m}}}$

0
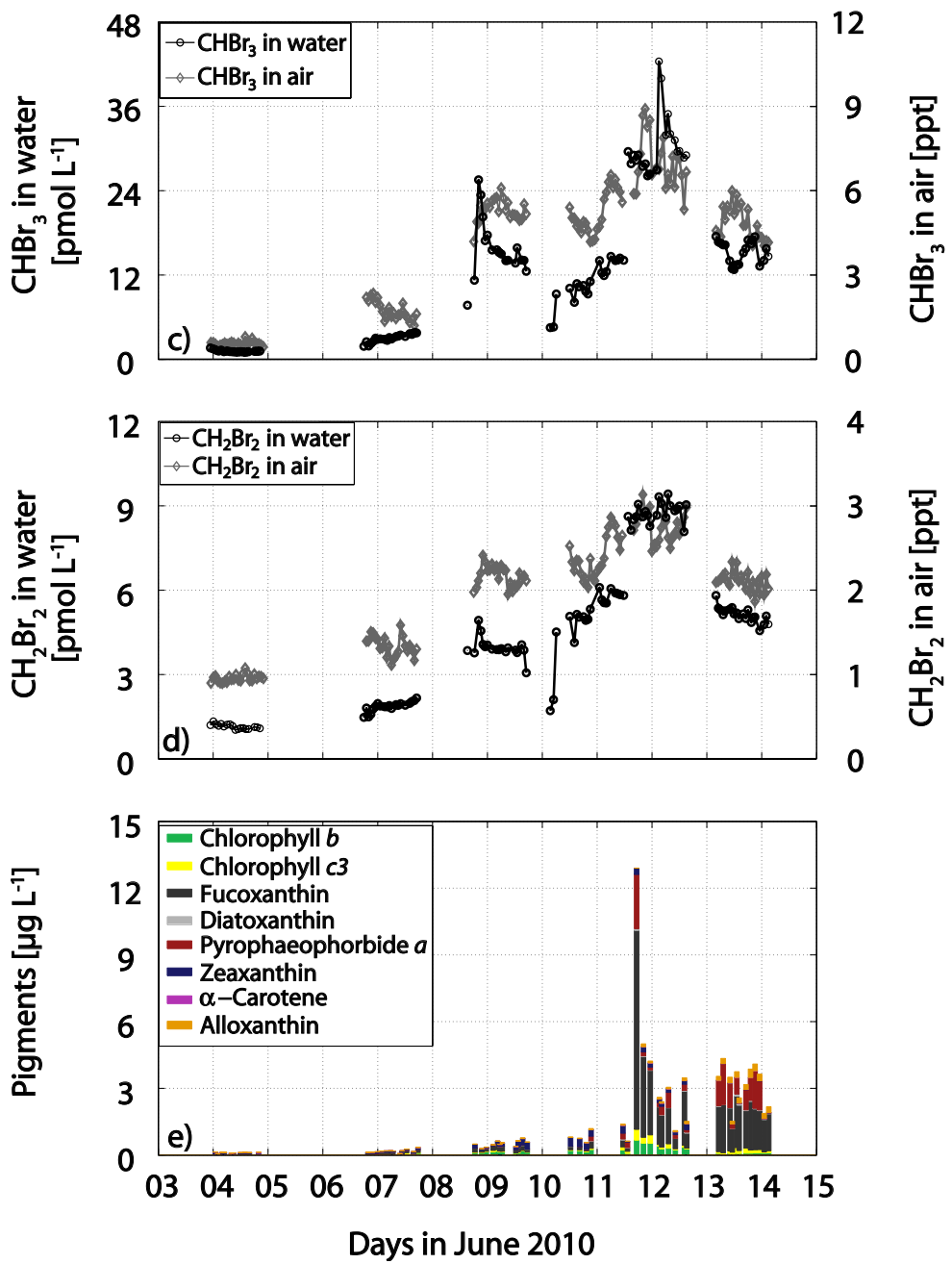

Fig. 2. SST, salinity and $\mathrm{Chl} a$ (a) along with halocarbon concentrations in water and atmospheric mixing ratios of $\mathrm{CH}_{3} \mathrm{I}(\mathbf{b})$, $\mathrm{CHBr}_{3}(\mathbf{c})$ and $\mathrm{CH}_{2} \mathrm{Br}_{2}$ (d) and pigments significant for the regional distribution of $\mathrm{CHBr}_{3}$ and $\mathrm{CH}_{2} \mathrm{Br}_{2}$ (e) during the DRIVE campaign. 
(1)

(2)
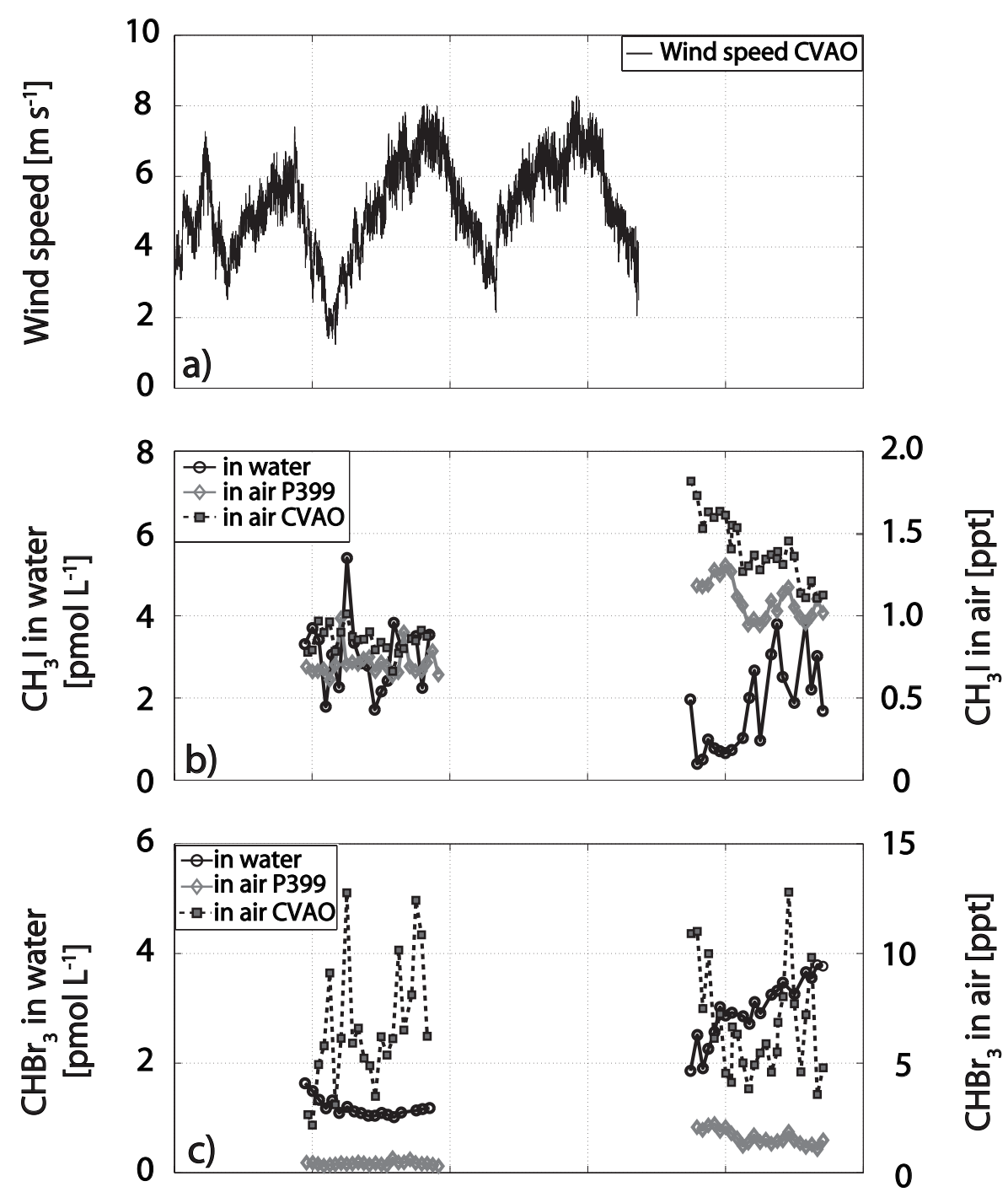

15
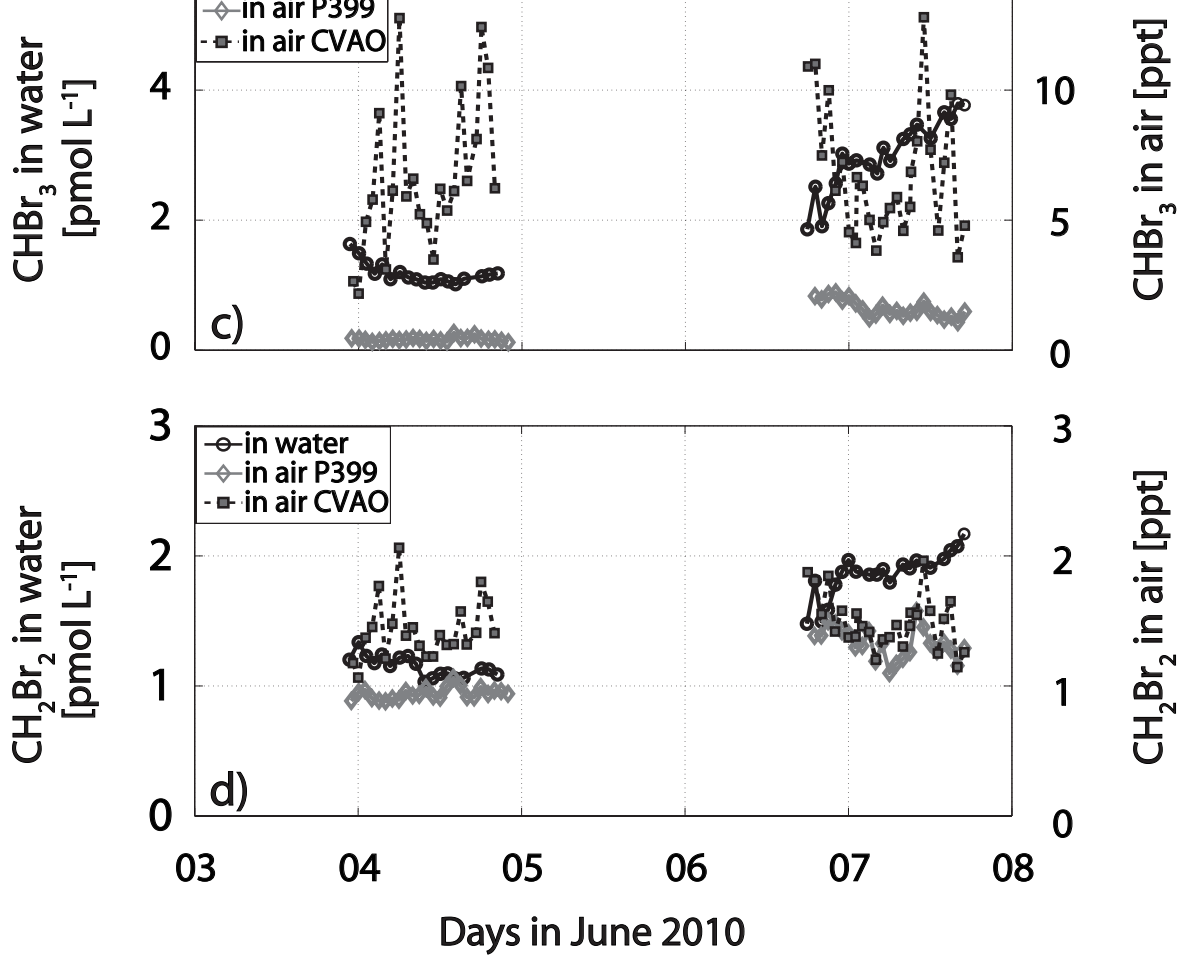

Fig. 3. Open ocean surface water and atmospheric halocarbons during stations $\mathrm{S} 1$ and $\mathrm{S} 2$ and atmospheric halocarbons measured parallel at CVAO as well as wind speed (wind speed in $\mathbf{a}, \mathrm{CH}_{3} \mathrm{I}$ in $\mathbf{b}, \mathrm{CHBr}_{3}$ in $\mathbf{c}$, and $\mathrm{CH}_{2} \mathrm{Br}_{2}$ in d). Wind speed data for 7 and 8 June in 2010 was not available. 


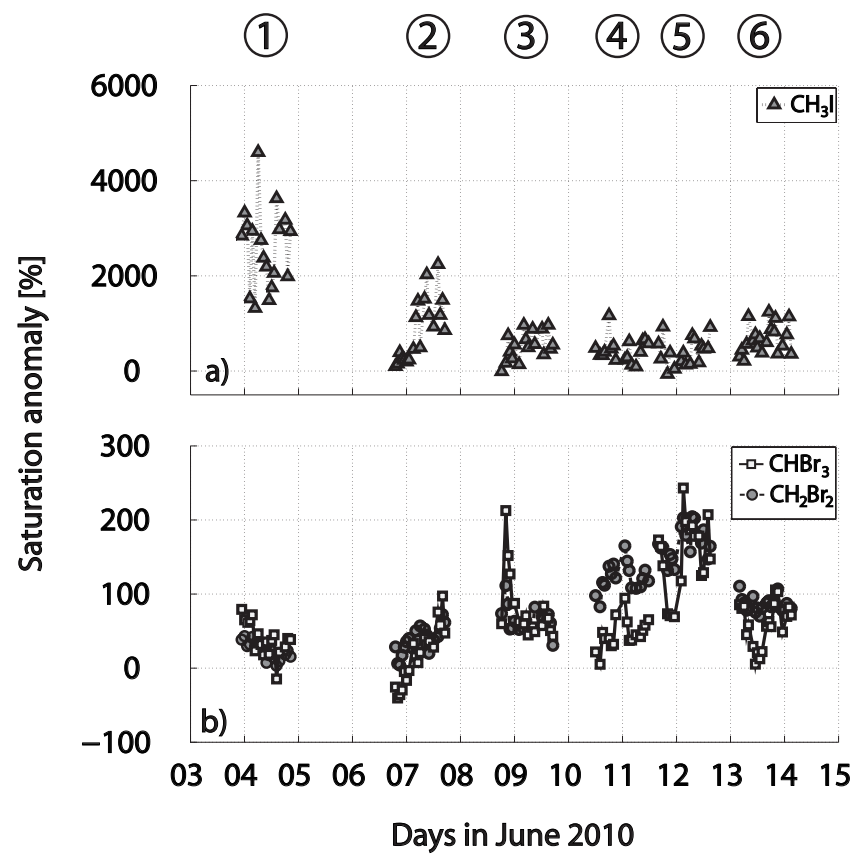

Fig. 4. Saturation anomalies of $\mathrm{CH}_{3} \mathrm{I}$ (a) and $\mathrm{CHBr}_{3}$ and $\mathrm{CH}_{2} \mathrm{Br}_{2}$ (b) throughout the RV Poseidon cruise.

at S3-S6, while wind speeds varied between 3.9 (S3) and $14.2 \mathrm{~m} \mathrm{~s}^{-1}$ (S6). At S5, the lowest MABL heights (close to the surface) together with the highest relative standard deviation (further on referred to as variability) in wind speed with a mean of $8.9 \mathrm{~m} \mathrm{~s}^{-1}$ and a variability of $27 \%$ was observed at one station in the course of $24 \mathrm{~h}$ (Table 1). Due to the classification of the stations into two regions, average values of both open ocean stations together are based on fewer measurements than average values of the four coastal stations.

\section{Results}

\subsection{Methyl iodide $\left(\mathrm{CH}_{3} \mathrm{I}\right)$}

\subsubsection{Regional distribution}

At the open ocean stations S1 and S2 higher mean oceanic $\mathrm{CH}_{3} \mathrm{I}$ of $2.4 \mathrm{pmol} \mathrm{L}^{-1}$ was found than at coastal stations S3S6 with a mean of $1.8 \mathrm{pmol} \mathrm{L}^{-1}$ (Fig. 2b, Table 2). The maximum mean oceanic $\mathrm{CH}_{3} \mathrm{I}$ of $3.0(1.7-5.4)$ pmol L $^{-1}$ was observed at $\mathrm{S} 1$, while $\mathrm{S} 3$ showed the lowest mean of $1.2(0.2-$ 2.1) $\mathrm{pmol} \mathrm{L}^{-1}$ during $24 \mathrm{~h}$. In total, the regional variability of $\mathrm{CH}_{3} \mathrm{I}$, which is the relative standard deviation between the means of the individual stations, was the lowest of all three halocarbons with $56 \%$. Correlations to neither phytoplankton pigments nor to picoplankton abundances were found for $\mathrm{CH}_{3} \mathrm{I}$ in sea surface water (Table 3).

Atmospheric $\mathrm{CH}_{3} \mathrm{I}$ with an overall mean of $1.3(0.6-$ 3.3) ppt revealed a different distribution in comparison to

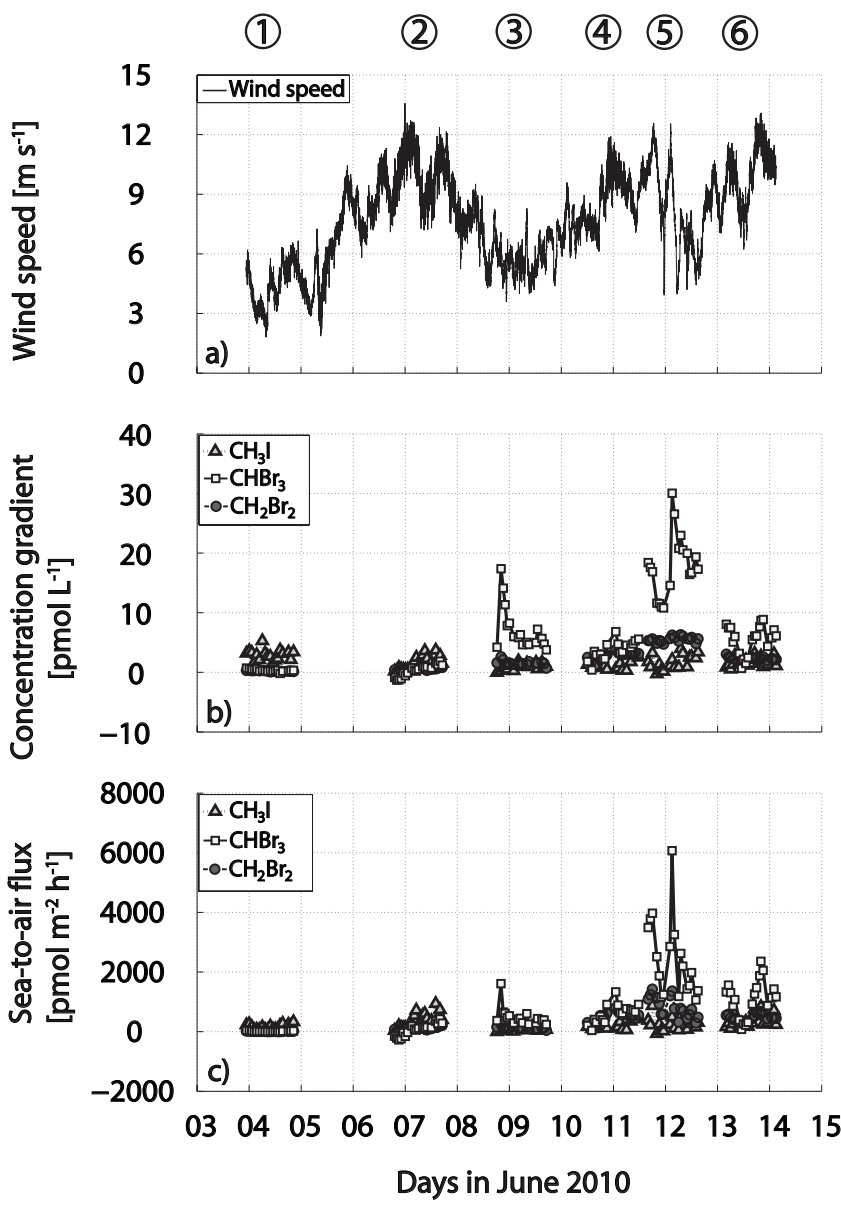

Fig. 5. Wind speed (a), concentration gradients (b) and sea-to-air fluxes (c) of $\mathrm{CH}_{3} \mathrm{I}, \mathrm{CHBr}_{3}$ and $\mathrm{CH}_{2} \mathrm{Br}_{2}$ during DRIVE.

oceanic $\mathrm{CH}_{3} \mathrm{I}$ (Fig. 2a). It was generally lower above the open ocean with $0.9(0.6-1.3)$ ppt on average and increased towards the coast with a mean (range) of $1.6(0.9-3.3) \mathrm{ppt}$ (see also Fuhlbrügge et al., 2013). In total, atmospheric $\mathrm{CH}_{3} \mathrm{I}$ had a lower regional variability of $44 \%$ than oceanic $\mathrm{CH}_{3} \mathrm{I}$.

\subsubsection{Diel variations}

Of all three halocarbons, oceanic $\mathrm{CH}_{3} \mathrm{I}$ showed the largest diel variability which was also larger than its regional variability. The lowest and the highest mean variability during $24 \mathrm{~h}$ were found at the open ocean stations S1 with $29 \%$ and at $\mathrm{S} 2$ with $62 \%$. At the coastal stations oceanic $\mathrm{CH}_{3} \mathrm{I}$ varied between $37 \%$ (S6) and $60 \%$ (S4). While at four stations maxima of $\mathrm{CH}_{3} \mathrm{I}$ in the surface water were found in the morning hours, elevations in the afternoon were observed at open ocean station S2 and coastal station S6. Hence, no overall diurnal cycle could be detected.

Low relative diel variability between $9 \%(\mathrm{~S} 2)$ and $11 \%$ (S1) was observed in atmospheric $\mathrm{CH}_{3} \mathrm{I}$ above the open ocean. The variability at CVAO at the same time ranged 
Table 2. Results of halocarbon measurements (water and air) and calculations (saturation anomalies and sea-to-air fluxes) for all six diel stations and parallel air sampling at CVAO.

\begin{tabular}{|c|c|c|c|c|c|c|c|c|}
\hline & & & $\mathrm{S} 1$ & $\mathrm{~S} 2$ & $\mathrm{~S} 3$ & S4 & S5 & S6 \\
\hline & & & $\begin{array}{l}17.6^{\circ} \mathrm{N} \text { and } \\
24.3^{\circ} \mathrm{W}\end{array}$ & $\begin{array}{l}18.0^{\circ} \mathrm{N} \text { and } \\
21.0^{\circ} \mathrm{W}\end{array}$ & $\begin{array}{l}18.0^{\circ} \mathrm{N} \text { and } \\
18.0^{\circ} \mathrm{W}\end{array}$ & $\begin{array}{l}18.5^{\circ} \mathrm{N} \text { and } \\
16.5^{\circ} \mathrm{W}\end{array}$ & $\begin{array}{l}19.0^{\circ} \mathrm{N} \text { and } \\
16.6^{\circ} \mathrm{W}\end{array}$ & $\begin{array}{l}20.0^{\circ} \mathrm{N} \text { and } \\
17.3^{\circ} \mathrm{W}\end{array}$ \\
\hline Compound & Parameter & Unit & & & & & & \\
\hline \multirow{5}{*}{$\mathrm{CH}_{3} \mathrm{I}$} & Water & $\mathrm{pmol} \mathrm{L}^{-1}$ & $\begin{array}{l}3.0 \\
(1.7-5.4)\end{array}$ & $\begin{array}{l}1.8 \\
(0.4-3.9)\end{array}$ & $\begin{array}{l}1.2 \\
(0.2-2.1)\end{array}$ & $\begin{array}{l}1.6 \\
(0.6-3.4)\end{array}$ & $\begin{array}{l}2.2 \\
(0.1-4.5)\end{array}$ & $\begin{array}{l}2.0 \\
(0.8-3.5)\end{array}$ \\
\hline & Air & ppt & $\begin{array}{l}0.7 \\
(0.6-1.0)\end{array}$ & $\begin{array}{l}1.1 \\
(1.0-1.3)\end{array}$ & $\begin{array}{l}1.0 \\
(0.9-1.1)\end{array}$ & $\begin{array}{l}1.6 \\
(1.1-2.7)\end{array}$ & $\begin{array}{l}2.3 \\
(1.4-3.3)\end{array}$ & $\begin{array}{l}1.3 \\
(1.1-2.7)\end{array}$ \\
\hline & CVAO air & ppt & $\begin{array}{l}0.9 \\
(0.7-1.0)\end{array}$ & $\begin{array}{l}1.4 \\
(1.1-1.8)\end{array}$ & - & - & - & - \\
\hline & Saturation anomaly & $\%$ & $\begin{array}{l}2606.3 \\
(1321.1-4597.1)\end{array}$ & $\begin{array}{l}870.2 \\
(99.4-2243.7)\end{array}$ & $\begin{array}{l}532.2 \\
(-8.5-967.1)\end{array}$ & $\begin{array}{l}445.6 \\
(90.8-1167.4)\end{array}$ & $\begin{array}{l}410.8 \\
(-65.8-928.7)\end{array}$ & $\begin{array}{l}672.1 \\
(210.1-1242.3)\end{array}$ \\
\hline & Sea-to-air flux & $\mathrm{pmol} \mathrm{m}^{-2} \mathrm{~h}^{-1}$ & $\begin{array}{l}158.3 \\
(59.3-330.4)\end{array}$ & $\begin{array}{l}372.6 \\
(39.6-941.6)\end{array}$ & $\begin{array}{l}79.0 \\
(-1.7-212.2)\end{array}$ & $\begin{array}{l}227.7 \\
(61.4-500.5)\end{array}$ & $\begin{array}{l}259.6 \\
(-64.6-871.6)\end{array}$ & $\begin{array}{l}382.5 \\
(106.1-837.9)\end{array}$ \\
\hline \multirow{5}{*}{$\mathrm{CHBr}_{3}$} & Water & $\mathrm{pmol} \mathrm{L}^{-1}$ & $\begin{array}{l}1.2 \\
(1.0-1.6)\end{array}$ & $\begin{array}{l}3.0 \\
(1.9-3.8)\end{array}$ & $\begin{array}{l}16.2 \\
(11.3-25.5)\end{array}$ & $\begin{array}{l}11.9 \\
(8.1-14.7)\end{array}$ & $\begin{array}{l}30.6 \\
(26.1-42.4)\end{array}$ & $\begin{array}{l}15.3 \\
(12.8-17.5)\end{array}$ \\
\hline & Air & ppt & $\begin{array}{l}0.6 \\
(0.5-0.8)\end{array}$ & $\begin{array}{l}1.8 \\
(1.2-2.4)\end{array}$ & $\begin{array}{l}5.3 \\
(4.2-6.1)\end{array}$ & $\begin{array}{l}5.3 \\
(4.2-6.6)\end{array}$ & $\begin{array}{l}7.0 \\
(5.4-8.9)\end{array}$ & $\begin{array}{l}4.9 \\
(4.1-6.0)\end{array}$ \\
\hline & CVAO air & ppt & $\begin{array}{l}6.7 \\
(2.3-12.8)\end{array}$ & $\begin{array}{l}6.8 \\
(3.7-12.8)\end{array}$ & - & - & - & - \\
\hline & Saturation anomaly & $\%$ & $\begin{array}{l}39.6 \\
(-14.7-79.3)\end{array}$ & $\begin{array}{l}17.7 \\
(-40.3-97.3)\end{array}$ & $\begin{array}{l}80.6 \\
(43.0-212.7)\end{array}$ & $\begin{array}{l}46.1 \\
(5.2-94.4)\end{array}$ & $\begin{array}{l}148.0 \\
(69.4-243.1)\end{array}$ & $\begin{array}{l}59.4 \\
(5.4-105.5)\end{array}$ \\
\hline & Sea-to-air flux & $\mathrm{pmol} \mathrm{m}^{-2} \mathrm{~h}^{-1}$ & $\begin{array}{l}15.5 \\
(-8.5-45.0)\end{array}$ & $\begin{array}{l}65.6 \\
(-273.4-426.7)\end{array}$ & $\begin{array}{l}489.1 \\
(241.4-1610.9)\end{array}$ & $\begin{array}{l}611.7 \\
(41.7-1333.8)\end{array}$ & $\begin{array}{l}2423.0 \\
(1063.3-6068.9)\end{array}$ & $\begin{array}{l}1098.2 \\
(77.8-2360.2)\end{array}$ \\
\hline \multirow{5}{*}{$\mathrm{CH}_{2} \mathrm{Br}_{2}$} & Water & $\mathrm{pmol} \mathrm{L}^{-1}$ & $\begin{array}{l}1.2 \\
(1.0-1.3)\end{array}$ & $\begin{array}{l}1.9 \\
(1.5-2.2)\end{array}$ & $\begin{array}{l}4.0 \\
(3.1-4.9)\end{array}$ & $\begin{array}{l}5.4 \\
(4.1-6.1)\end{array}$ & $\begin{array}{l}8.8 \\
(8.1-9.4)\end{array}$ & $\begin{array}{l}5.1 \\
(4.6-5.8)\end{array}$ \\
\hline & Air & ppt & $\begin{array}{l}1.0 \\
(0.9-1.1)\end{array}$ & $\begin{array}{l}1.4 \\
(1.1-1.6)\end{array}$ & $\begin{array}{l}2.2 \\
(2.0-2.4)\end{array}$ & $\begin{array}{l}2.4 \\
(2.0-2.9)\end{array}$ & $\begin{array}{l}2.8 \\
(2.5-3.1)\end{array}$ & $\begin{array}{l}2.1 \\
(1.9-2.3)\end{array}$ \\
\hline & CVAO air & ppt & $\begin{array}{l}1.4 \\
(1.1-2.1)\end{array}$ & $\begin{array}{l}1.5 \\
(1.2-2.0)\end{array}$ & - & - & - & - \\
\hline & Saturation anomaly & $\%$ & $\begin{array}{l}24.7 \\
(3.4-43.2)\end{array}$ & $\begin{array}{l}37.7 \\
(4.1-72.2)\end{array}$ & $\begin{array}{l}64.7 \\
(30.9-111.5)\end{array}$ & $\begin{array}{l}122.0 \\
(82.7-165.0)\end{array}$ & $\begin{array}{l}169.0 \\
(131.8-204.3)\end{array}$ & $\begin{array}{l}86.1 \\
(70.1-110.6)\end{array}$ \\
\hline & Sea-to-air flux & $\mathrm{pmol} \mathrm{m}^{-2} \mathrm{~h}^{-1}$ & $\begin{array}{l}10.6 \\
(1.8-27.9)\end{array}$ & $\begin{array}{l}118.5 \\
(14.5-214.3)\end{array}$ & $\begin{array}{l}115.7 \\
(50.0-260.3)\end{array}$ & $\begin{array}{l}511.8 \\
(207.9-801.0)\end{array}$ & $\begin{array}{l}815.4 \\
(285.6-1429.4)\end{array}$ & $\begin{array}{l}470.4 \\
(295.5-671.6)\end{array}$ \\
\hline
\end{tabular}

between $9 \%$ (4 June, parallel to S1) and $14 \%$ (June 6 and 7, parallel to S2) (Fig. 3a, Table 2) with mean mixing ratios of $1.2 \mathrm{ppt}$ (0.7 ppt, 4 June-1.8 ppt, 6 June). At the coastal stations S3-S6, diel variability of 7 (S3) - 33\% (S4) was observed. The highest mean atmospheric variability at $\mathrm{S} 4$ coincides with the largest oceanic variability. Similarly to oceanic $\mathrm{CH}_{3} \mathrm{I}$, there is no overall diurnal cycle in atmospheric mixing ratios. Maxima and minima occurred in both day and night hours.

\subsubsection{Saturation anomaly, sea-air concentration gradient and sea-to-air fluxes}

Saturation anomalies (Fig. 4), concentration gradient (Fig. 5b) as well as sea-to-air fluxes (Fig. 5c) were calculated according to Eqs. (1)-(3) (Table 2). To constrain the atmospheric influence on the concentration gradient, thus on the sea-to-air fluxes, the fraction of the equilibrium concentration $c_{\mathrm{atm}} / H$ of the oceanic concentration $c_{\mathrm{w}}$ was calculated (Fig. 6a). This is the relative reduction of the sea-to-air flux by the atmospheric mixing ratios compared to an empty atmosphere, which will be referred to as "flux reducing effect" further on.
For $\mathrm{CH}_{3} \mathrm{I}$ the highest saturation anomalies with means of 931 (-66-4597)\% (Fig. 4a, Table 2) and the lowest concentration gradients of $1.7(-0.3-5.3) \mathrm{pmol} \mathrm{L}^{-1}$ (Fig. 5b) of the three halocarbons were calculated for $\mathrm{CH}_{3} \mathrm{I}$ for the whole cruise. Both were consistent with the oceanic distribution: they were highest in the open ocean with maxima at S1 where however no high emissions of this compound were calculated because of the prevailing low wind speeds during that time (Fig. 5c). The open ocean was generally highly supersaturated with mean anomalies of $1715 \%$ on average, decreasing towards the coastal stations to a mean of $522 \%$. The reducing effect of atmospheric $\mathrm{CH}_{3} \mathrm{I}$ on the sea-to-air flux was low, usually less than $50 \%$. One exception was S5 where low oceanic $\mathrm{CH}_{3} \mathrm{I}$ coincided with high atmospheric mixing ratios, and the flux reducing effect reached $300 \%$ leading to a flux into the water. Mainly positive sea-to-air fluxes of $\mathrm{CH}_{3} \mathrm{I}$ could be observed with a mean of $254 \mathrm{pmol} \mathrm{m}^{-2} \mathrm{~h}^{-1}$ for the whole cruise ( -65 at coastal station S5 to $942 \mathrm{pmol} \mathrm{m}^{-2} \mathrm{~h}^{-1}$ at open ocean station S2) (Fig. 5c, Table 2). Open ocean and mean coastal fluxes of 268 and $246 \mathrm{pmol} \mathrm{m}^{-2} \mathrm{~h}^{-1}$, respectively were in a similar range though with potentially higher fluxes in the open ocean due to its large supersaturation there. 
Table 3. Correlation coefficients $R^{2}$ of halocarbons to nano- and picoplankton abundances as well as to phytoplankton pigment data (MLR Multiple Linear Regression). The correlations to Prochlorococchus are all significant on the $\mathrm{p}<0.05$ level. Negative correlations are printed in italic.

\begin{tabular}{llllll}
\hline & & $\mathrm{CH}_{3} \mathrm{I}$ & $\mathrm{CHBr}_{3}$ & $\mathrm{CH}_{2} \mathrm{Br}_{2}$ \\
\hline \multirow{2}{*}{ Nano- and picoplankton } & Prochlorococcus & 72 & 0.10 & 0.39 & 0.26 \\
& Others & 72 & $<0.08$ & $<0.09$ & $<0.10$ \\
\hline \multirow{2}{*}{ Phyotplankton pigments } & $\mathrm{Chl} a$ & 61 & 0.00 & 0.38 & 0.49 \\
& MLR & 61 & None & 0.79 & 0.77 \\
\hline
\end{tabular}

\subsubsection{Impact of oceanic $\mathrm{CH}_{3} \mathrm{I}$ and wind speed on fluxes}

The sea-to-air flux of $\mathrm{CH}_{3} \mathrm{I}$ showed significant but low regional correlations with sea surface concentrations $\left(R^{2}=0.37\right)$ and wind speed $\left(R^{2}=0.24\right)$ for the whole cruise (Fig. 7a, d, Table 4). Considering each station individually, high significant correlations of oceanic $\mathrm{CH}_{3} \mathrm{I}$ and sea-to-air flux were found at open ocean station S2 and at all coastal stations with $R^{2}$ ranging between 0.57 and 0.91 . Significant correlations of wind speed to the $\mathrm{CH}_{3} \mathrm{I}$ sea-to-air flux only existed at coastal station S3 and open ocean station S1 $\left(R^{2}=0.24\right.$ and 0.76$)$.

\subsection{Bromoform $\left(\mathrm{CHBr}_{3}\right)$ and dibromomethane $\left(\mathrm{CH}_{2} \mathrm{Br}_{2}\right)$}

\subsubsection{Regional distribution}

$\mathrm{CHBr}_{3}$ and $\mathrm{CH}_{2} \mathrm{Br}_{2}$ were both lower in the open ocean with means of $2.3(1.0-3.8) \mathrm{pmol} \mathrm{L}^{-1}$ for $\mathrm{CHBr}_{3}$ and $1.6(1.0-$ 2.2) $\mathrm{pmol} \mathrm{L}^{-1}$ for $\mathrm{CH}_{2} \mathrm{Br}_{2}$ with minimum concentrations occurring at $\mathrm{S} 1$ (Fig. 2c, d, Table 2). Both compounds had higher coastal concentrations of $18.3(8.1-42.4) \mathrm{pmol} \mathrm{L}^{-1}$ for $\mathrm{CHBr}_{3}$ and 5.8 (3.1-9.4) pmol L $\mathrm{L}^{-1}$ for $\mathrm{CH}_{2} \mathrm{Br}_{2}$ with maxima at $\mathrm{S} 5$ and a much more pronounced increase in oceanic $\mathrm{CHBr}_{3}$ than in $\mathrm{CH}_{2} \mathrm{Br}_{2}$. $\mathrm{CHBr}_{3}$ and $\mathrm{CH}_{2} \mathrm{Br}_{2}$ in sea surface water demonstrated much higher relative regional variability of $78 \%\left(\mathrm{CHBr}_{3}\right)$ and $59 \%\left(\mathrm{CH}_{2} \mathrm{Br}_{2}\right)$ than oceanic $\mathrm{CH}_{3} \mathrm{I}$.

Atmospheric $\mathrm{CHBr}_{3}$ and $\mathrm{CH}_{2} \mathrm{Br}_{2}$ increased towards the coast similarly to their oceanic counterparts (Fig. 2c, d, Table 2). The highest mean regional variability was found for $\mathrm{CHBr}_{3}\left(56 \%\right.$ ), while atmospheric $\mathrm{CH}_{2} \mathrm{Br}_{2}$ showed the lowest $(33 \%)$ of the three halocarbons.

\subsubsection{Diel variations}

Diel variations of both $\mathrm{CHBr}_{3}$ and $\mathrm{CH}_{2} \mathrm{Br}_{2}$ in sea surface water were generally lower than their regional variations. The variability of $\mathrm{CHBr}_{3}$ ranged between $14 \%$ (S1) and $19 \%$ (S2) in the open ocean, while the variability of $\mathrm{CH}_{2} \mathrm{Br}_{2}$ was even lower with $7 \%$ (S1) and $9 \%$ (S2). At most of the coastal stations $\mathrm{CHBr}_{3}$ and $\mathrm{CH}_{2} \mathrm{Br}_{2}$ revealed similar distributions throughout $24 \mathrm{~h}$ with maxima in the evening and night hours with the exception of S5 where maxima
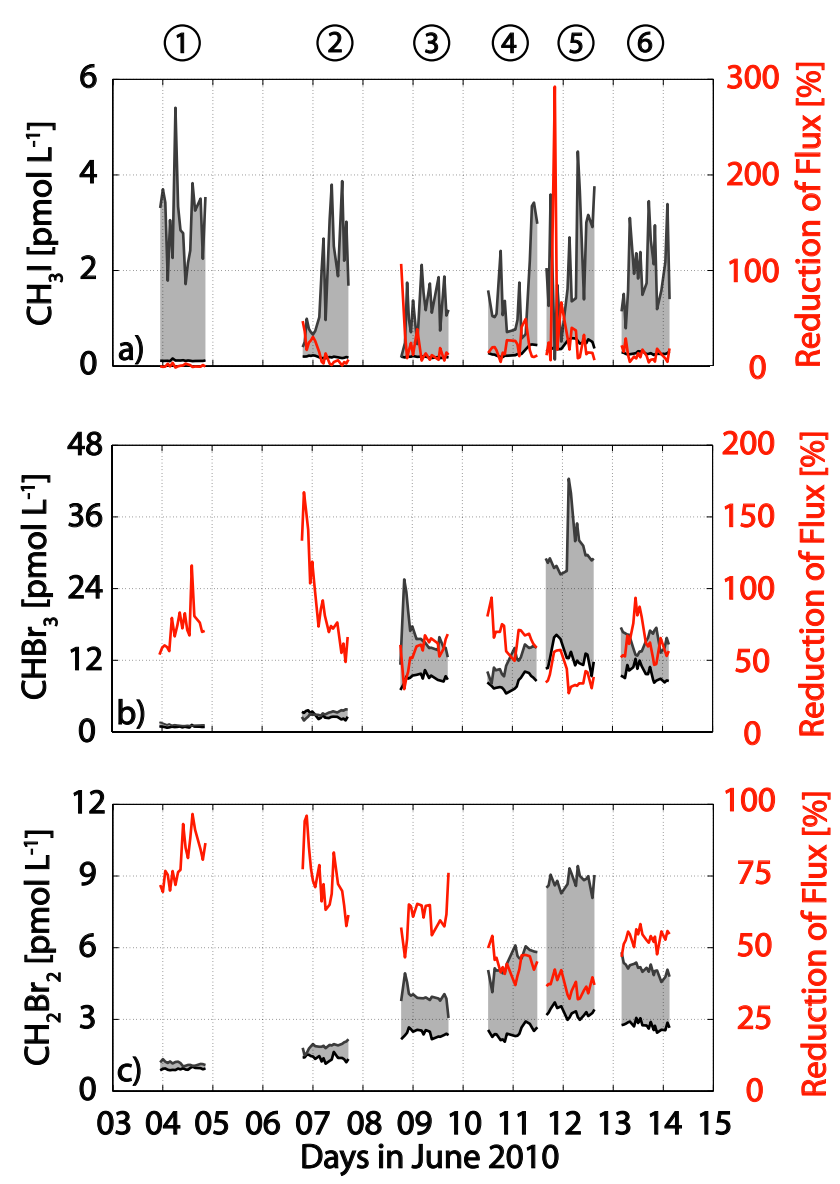

Fig. 6. Influence of atmospheric mixing ratios on the amount of oceanic halocarbons emitted for $\mathrm{CH}_{3} \mathrm{I}$ (a), $\mathrm{CHBr}_{3}$ (b), and $\mathrm{CH}_{2} \mathrm{Br}_{2}$ (c). Oceanic concentrations are plotted in grey (left axis), the equilibrium concentration is delineated in black, and the concentration gradient is shaded in grey. The percentaged reduction of the concentration gradient by the equilibrium concentration (flux reducing effect) derived from the atmospheric measurements (equilibrium concentration in percent in relation to the water concentrations) is shown in red (right axis). Values above $100 \%$ refer to fluxes from the atmosphere into the ocean. 

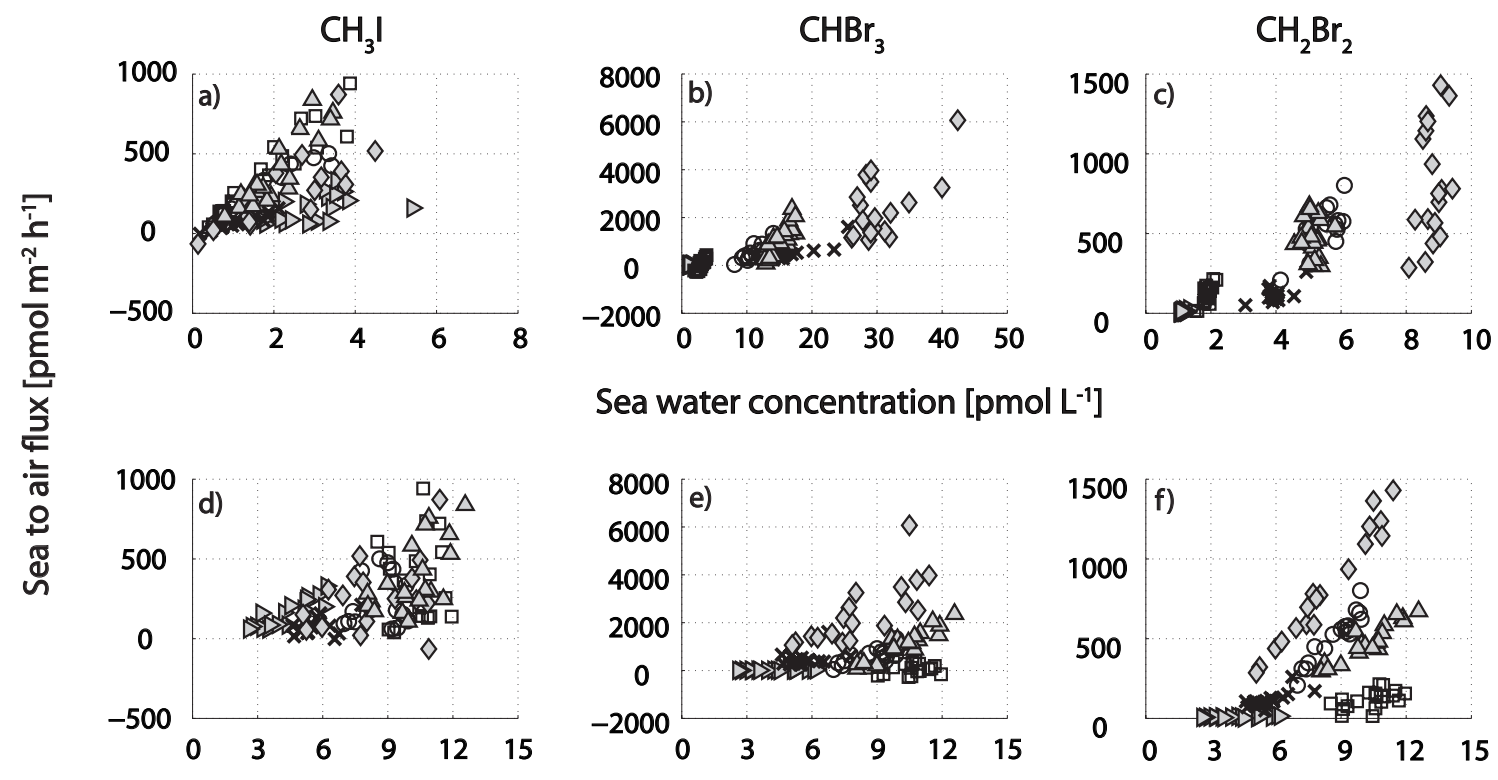

Sea water concentration [pmol L-1]
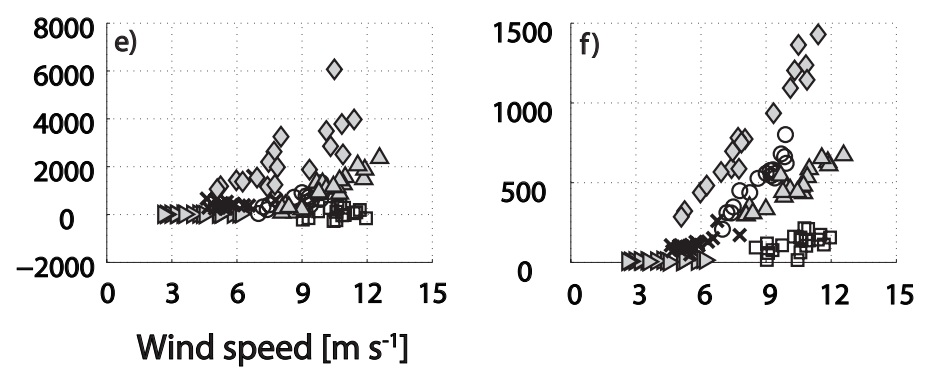

$\triangle(1) \quad \square$ (2) $\quad \times(3) \quad \bigcirc(4) \quad \diamond(5) \quad \triangle(6)$

Fig. 7. Sea-to-air fluxes versus sea water concentrations of $\mathrm{CH}_{3} \mathrm{I}(\mathbf{a}), \mathrm{CHBr}_{3}$ (b) and $\mathrm{CH}_{2} \mathrm{Br}_{2}$ (c) and wind speed (d-f) during DRIVE.

of $42.4 \mathrm{pmol} \mathrm{L}^{-1}\left(\mathrm{CHBr}_{3}\right)$ and $9.4 \mathrm{pmol} \mathrm{L}^{-1}\left(\mathrm{CH}_{2} \mathrm{Br}_{2}\right)$ were found in the morning hours. The highest diel variation of $23 \%$ was found at coastal station $\mathrm{S} 3$ for oceanic $\mathrm{CHBr}_{3}$, while $\mathrm{CH}_{2} \mathrm{Br}_{2}$ was generally less variable ranging from 4 (S5) to $10 \%$ (S4).

Atmospheric mixing ratios of bromocarbons were low at the open ocean stations S1-S2 with means between 0.6 and $1.78 \mathrm{ppt}$ and relative standard deviations of $13-19 \%$ for $\mathrm{CHBr}_{3}$ and atmospheric $\mathrm{CH}_{2} \mathrm{Br}_{2}$ ranging on average between 1.0 and $1.4 \mathrm{ppt}$ with a relative standard deviation of 5-9\%. At CVAO mean mixing ratios of 6.7-6.8 ppt $\mathrm{CHBr}_{3}$ and of $1.4-1.5 \mathrm{ppt} \mathrm{CH}_{2} \mathrm{Br}_{2}$ were higher than at $\mathrm{S} 1-\mathrm{S} 2$, as was their diel variability ranging from $35-43 \%$ for $\mathrm{CHBr}_{3}$ and $14-16 \%$ for $\mathrm{CH}_{2} \mathrm{Br}_{2}$ (Fig. 3b, c, Table 2). The highest atmospheric $\mathrm{CHBr}_{3}$ during the whole campaign of $12.8 \mathrm{ppt}$ was measured at CVAO on 7 June. The diel variability of atmospheric $\mathrm{CHBr}_{3}$ at the coastal stations S3-S6 was generally lower than what was observed above the open ocean with 7 (S3)-14\% (S4) and means of 4.8 (S6)-7.0 ppt (S5). The diel variability of atmospheric $\mathrm{CH}_{2} \mathrm{Br}_{2}$ at the coast was similar to the open ocean with 5 (S6)-10\% (S4) and means of 2.1 (S6)-2.8 ppt (S5). Atmospheric $\mathrm{CHBr}_{3}$ and $\mathrm{CH}_{2} \mathrm{Br}_{2}$ showed no overall diurnal cycles above neither open ocean nor coastal stations with maxima during both day and night hours.

\subsubsection{Correlations of $\mathrm{CHBr}_{3}$ and $\mathrm{CH}_{2} \mathrm{Br}_{2}$ with phytoplankton pigments}

Surface water concentrations of $\mathrm{CHBr}_{3}$ and $\mathrm{CH}_{2} \mathrm{Br}_{2}$ correlated significantly with $\mathrm{Chl} a$ at the $95 \%$ level with correlation coefficients $R^{2}$ of 0.38 and 0.49 (Table 3, Figure 2a). Multiple linear regressions (MLR) of brominated halocarbons to all phytoplankton marker pigments were carried out for the whole cruise. All pigment data related to $\mathrm{CHBr}_{3}$ or $\mathrm{CH}_{2} \mathrm{Br}_{2}$ with $\mathrm{p}<0.05$ was regarded as significant. The six pigments chlorophyll $b$, chlorophyll $c 3$, fucoxanthin, diatoxanthin, pyrophaeophorbide $a$ and zeaxanthin were found to describe the regional distribution of $\mathrm{CHBr}_{3}$ best (Fig. 2e, Table 3). Chlorophyll $b$, fucoxanthin, $\alpha$-carotene (negatively correlated) and alloxanthin were important for $\mathrm{CH}_{2} \mathrm{Br}_{2}$ in the order of explanatory power. Additionally, significant but low correlations of $\mathrm{CHBr}_{3}$ and $\mathrm{CH}_{2} \mathrm{Br}_{2}$ were found to Prochlorococcus with $R^{2}=0.39$ and $R^{2}=0.26$ (negatively correlated).

\subsubsection{Saturation anomaly, sea-air concentration gradients and sea-to-air fluxes}

The ocean was generally supersaturated with $\mathrm{CHBr}_{3}$ and $\mathrm{CH}_{2} \mathrm{Br}_{2}$ (Fig. 4, Table 2). The overall saturation anomaly of $65(-40-243) \%$ for $\mathrm{CHBr}_{3}$ was slightly lower than the mean of $\mathrm{CH}_{2} \mathrm{Br}_{2}$ with 84 (3-204)\% (Fig. 4b). Both displayed similar trends opposite to $\mathrm{CH}_{3} \mathrm{I}$ : lower anomalies of around $30 \%$ in the open ocean stations, increasing towards the coastal stations S3 - S6 with means of 
$83 \%$ for $\mathrm{CHBr}_{3}$ and $110 \%$ for $\mathrm{CH}_{2} \mathrm{Br}_{2}$. Maximum saturation anomalies coincided with maximum oceanic and atmospheric bromocarbons at S5 with daily means of $148 \%$ for $\mathrm{CHBr}_{3}$ and $169 \%$ for $\mathrm{CH}_{2} \mathrm{Br}_{2}$. The concentration gradient $c_{\mathrm{W}}-c_{\mathrm{atm}} / H$ of $\mathrm{CHBr}_{3}$ was the highest of all three halocarbons with a total mean of $5.8(-1.3-30.0) \mathrm{pmol} \mathrm{L}^{-1}$, followed by $\mathrm{CH}_{2} \mathrm{Br}_{2}$ with a mean of $2.2(0-6.3) \mathrm{pmol} \mathrm{L}^{-1}$ and minima in the open ocean region (Fig. 5b). The reducing effect of atmospheric $\mathrm{CHBr}_{3}$ and $\mathrm{CH}_{2} \mathrm{Br}_{2}$ on the sea-to-air flux was $>75 \%$ in the open ocean where both compounds were close to equilibrium and decreases simultaneously with the strongly increasing concentration gradient towards the coast (Fig. 6b, c). For $\mathrm{CHBr}_{3}$ and $\mathrm{CH}_{2} \mathrm{Br}_{2}$ the flux reducing effect was around $50 \%$ at the four coastal stations (S3-S6). Sea-to-air fluxes of $\mathrm{CHBr}_{3}$ and $\mathrm{CH}_{2} \mathrm{Br}_{2}$ for the whole cruise were on average higher than $\mathrm{CH}_{3}$ I fluxes with $787(-273-$ 6069) pmol m $\mathrm{m}^{-2} \mathrm{~h}^{-1}$ and 341 (2-1429) $\mathrm{pmol} \mathrm{m}^{-2} \mathrm{~h}^{-1}$, respectively (Fig. 5c, Table 2). Fluxes of both compounds were low in the open ocean region with means of $41 \mathrm{pmol} \mathrm{m}^{-2} \mathrm{~h}^{-1}$ for $\mathrm{CHBr}_{3}$ and of $66 \mathrm{pmol} \mathrm{m}^{-2} \mathrm{~h}^{-1}$ for $\mathrm{CH}_{2} \mathrm{Br}_{2}$. Higher seato-air fluxes of $\mathrm{CHBr}_{3}$ and $\mathrm{CH}_{2} \mathrm{Br}_{2}$ with means of 1171 and $483 \mathrm{pmol} \mathrm{m}^{-2} \mathrm{~h}^{-1}$ were observed at the coastal stations S3S6. The maximum fluxes of both compounds were found at coastal station 5 .

\subsubsection{Impact of oceanic $\mathrm{CHBr}_{3}$ and $\mathrm{CH}_{2} \mathrm{Br}_{2}$ and wind speed on fluxes}

Sea surface water concentrations of $\mathrm{CHBr}_{3}$ and $\mathrm{CH}_{2} \mathrm{Br}_{2}$ correlated regionally to sea-to-air fluxes with $R^{2}=0.68$ $\left(\mathrm{CHBr}_{3}\right)$ and $0.71\left(\mathrm{CH}_{2} \mathrm{Br}_{2}\right)$ for the whole cruise (Fig. 7, Table 4). Significant correlations of $\mathrm{CHBr}_{3}$ fluxes with sea surface water concentrations were found at all $24 \mathrm{~h}$-stations $\left(R^{2}\right.$ from 0.34 to 0.78 ). The highest correlations of sea surface $\mathrm{CH}_{2} \mathrm{Br}_{2}$ to its sea-to-air fluxes were found at open ocean station S2 (0.64) and coastal stations S3 and S4 $(0.42,0.53)$. No significant correlations could be observed at coastal stations S5 and S6. In contrast, wind speed showed low but regionally significant correlations to the overall sea-to-air fluxes with $R^{2}=0.14\left(\mathrm{CHBr}_{3}\right)$ and $R^{2}=0.29\left(\mathrm{CH}_{2} \mathrm{Br}_{2}\right)$. Considering the stations individually, $\mathrm{CHBr}_{3}$ and $\mathrm{CH}_{2} \mathrm{Br}_{2}$ revealed high correlations of wind speed with sea-to-air flux at coastal stations S4-S6 with $R^{2}$ from 0.56 to 0.95 .

\section{Discussion}

\subsection{Sea-to-air fluxes of $\mathrm{CH}_{3} \mathrm{I}$}

\subsubsection{Oceanic and atmospheric $\mathrm{CH}_{3} \mathrm{I}$ as drivers of the regional and diel variability of the concentration gradient}

The ocean was highly supersaturated with $\mathrm{CH}_{3} \mathrm{I}$ throughout most of the cruise which is underlined by the low impact of atmospheric $\mathrm{CH}_{3} \mathrm{I}$ on its concentration gradient (Fig. 6a).
Table 4. Correlation coefficients for water concentrations of halocarbons and wind speed with sea-to-air fluxes of halocarbons for the whole cruise and for the individual stations. Coefficients printed in bold represent significant correlations with $p<0.05$.

\begin{tabular}{|c|c|c|c|c|c|}
\hline \multirow[t]{2}{*}{ Station } & \multirow[t]{2}{*}{$R^{2}$ of } & \multicolumn{3}{|c|}{ with F of } & \multirow[t]{2}{*}{$n$} \\
\hline & & $\mathrm{CH}_{3} \mathrm{I}$ & $\mathrm{CHBr}_{3}$ & $\mathrm{CH}_{2} \mathrm{Br}_{2}$ & \\
\hline \multirow{2}{*}{ Whole cruise } & Water conc. & 0.37 & 0.68 & 0.71 & \multirow{2}{*}{109} \\
\hline & Wind speed & 0.24 & 0.14 & 0.29 & \\
\hline \multirow{2}{*}{$\mathrm{S} 1$} & Water conc. & 0.24 & 0.66 & 0.35 & \multirow{2}{*}{18} \\
\hline & Wind speed & 0.73 & 0.28 & 0.21 & \\
\hline \multirow{2}{*}{$\mathrm{S} 2$} & Water conc. & 0.89 & 0.78 & 0.64 & \multirow{2}{*}{19} \\
\hline & Wind speed & 0.00 & 0.00 & 0.15 & \\
\hline \multirow{2}{*}{ S3 } & Water conc. & 0.67 & 0.66 & 0.42 & \multirow{2}{*}{17} \\
\hline & Wind speed & 0.24 & 0.21 & 0.56 & \\
\hline \multirow{2}{*}{ S4 } & Water conc. & 0.91 & 0.60 & 0.53 & \multirow{2}{*}{17} \\
\hline & Wind speed & 0.02 & 0.67 & 0.93 & \\
\hline \multirow{2}{*}{ S5 } & Water conc. & 0.57 & 0.34 & 0.09 & \multirow{2}{*}{18} \\
\hline & Wind speed & 0.02 & 0.55 & 0.95 & \\
\hline \multirow{2}{*}{ S6 } & Water conc. & 0.79 & 0.70 & 0.00 & \multirow{2}{*}{20} \\
\hline & Wind speed & 0.06 & 0.82 & 0.78 & \\
\hline
\end{tabular}

Regional and diel variability in the concentration gradient was primarily a result of varying oceanic $\mathrm{CH}_{3} \mathrm{I}$. The oceanic concentrations during DRIVE $\left(0.1\right.$ to $5.4 \mathrm{pmol} \mathrm{L}^{-1}$, Table 2) compare well to the measurements by Schall et al. (1997) of $0-3 \mathrm{pmol} \mathrm{L}^{-1}$ in the Atlantic, north of $42^{\circ} \mathrm{N}$ during boreal wintertime. In contrast, Richter and Wallace (2004) measured 3-5 times higher oceanic $\mathrm{CH}_{3} \mathrm{I}$ with 7.1$16.4 \mathrm{pmol} \mathrm{L}^{-1}$ in boreal fall south of $15^{\circ} \mathrm{N}$, and Jones et al. (2010) reported even 6 times higher concentrations (total range from min to max: $1.0-36.5 \mathrm{pmol} \mathrm{L}^{-1}$, data from Jones et al., 2010; Ziska et al., 2013) in the same region and season. Similarly to DRIVE, Jones et al. (2010) found no significant difference between open ocean and coastal regions which was ascribed to photochemical sources supported by the incubation experiments of Richter and Wallace (2004) from the equatorial Atlantic. Richter (2004) found a relationship of oceanic $\mathrm{CH}_{3} \mathrm{I}$ with wind speed within this data which was not found during DRIVE: lower wind speeds led to elevated oceanic $\mathrm{CH}_{3} \mathrm{I}$. The much more elevated oceanic $\mathrm{CH}_{3} \mathrm{I}$ of Jones et al. (2010) was measured in our study region and season. A possible explanation for their largely elevated $\mathrm{CH}_{3} \mathrm{I}$ concentrations compared to our and other open ocean values (Ziska et al., 2013) might be enhanced photochemistry, but more detailed information is not given in the study of Jones et al. (2010). Smythe-Wright et al. (2006) measured $\mathrm{CH}_{3} \mathrm{I}$ as high as $45 \mathrm{pmolL}^{-1}$ in the Atlantic region south of $40^{\circ} \mathrm{N}$ in late summer which was accompanied by high Prochlorococcus abundance. In contrast, no outstanding relationship of $\mathrm{CH}_{3} \mathrm{I}$ with picoplankton including Prochlorococcus or the marker pigment divinyl chlorophyll $a$ indicative of these species was found during DRIVE. Additionally, no correlation with diatom pigments as suggested by Lai et al. (2011) for the production of open ocean $\mathrm{CH}_{3} \mathrm{I}$ was 
observed, supporting photochemistry as important production pathway for its formation as suggested by Moore and Zafiriou (1994). The likely non-biological formation of $\mathrm{CH}_{3} \mathrm{I}$ also leads to high saturation anomalies in open ocean surface waters. The lower saturation anomalies in the coastal zone might likely be a result of upwelled water diluting the more concentrated surface water (Happell and Wallace, 1996) combined with the elevated atmospheric $\mathrm{CH}_{3} \mathrm{I}$ above the upwelling. The large supersaturation of $\mathrm{CH}_{3} \mathrm{I}$ in surface water of the open ocean region indicates their potential for largely elevated sea-to-air fluxes in contrast to the coastal area. However, $\mathrm{CH}_{3} \mathrm{I}$ production may not be completely independent of biological parameters. Lacking correlations of $\mathrm{CH}_{3}$ I concentrations with pigment and flow cytometry data does not necessarily allow for excluding a biological source completely. The concentrations are a result of production and loss processes, which may partly be temporally and spatially decoupled. Another possible source for $\mathrm{CH}_{3} \mathrm{I}$ involves bacteria (Manley and Dastoor, 1998; Amachi et al., 2001; Fuse et al., 2003) which has not been taken into account during DRIVE. Additionally, Bell et al. (2002) suggested that organic precursors from phytoplankton production could be involved in the photochemical formation of $\mathrm{CH}_{3} \mathrm{I}$ in the surface ocean.

Atmospheric $\mathrm{CH}_{3} \mathrm{I}$ (0.6 to $3.3 \mathrm{ppt}$ ) measured during DRIVE falls well within the range of tropical Atlantic values reported by Williams et al. (2007) of 1.4 (0.6-3.0) ppt. Air mass back trajectory analysis and similar ranges of atmospheric $\mathrm{CH}_{3} \mathrm{I}$ at open ocean station $\mathrm{S} 1$ and parallel at CVAO on Cape Verde indicate open ocean air masses at both locations on 4 June (Fuhlbrügge et al., 2013). Wind speed at Cape Verde was highly variable on June 6 (Fig. 3d) leading to high variations in local sea-to-air fluxes likely causing the observed higher mean variability in atmospheric $\mathrm{CH}_{3} \mathrm{I}$ at $\mathrm{CVAO}$ parallel to open ocean station S2 (Sect. 4.1.2, Fig. 3a). Atmospheric $\mathrm{CH}_{3} \mathrm{I}$ during DRIVE at CVAO (0.7-1.8 ppt) was generally lower than the $1.2-13.8 \mathrm{ppt}$ detected by O'Brien et al. (2009) in a similar season.

Non-biological or indirect biological formation mechanisms in the surface water seem likely since the variability in oceanic $\mathrm{CH}_{3} \mathrm{I}$ was not correlated to the measured biological variables. Although a biological source cannot completely be excluded, the abiotic formation thus appears as main driver for variations of its concentration gradient across the air-sea interface with negligible influence from atmospheric $\mathrm{CH}_{3} \mathrm{I}$ on oceanic concentrations.

\subsubsection{The relative influence of concentration gradient and wind speed on sea-to-air fluxes of $\mathrm{CH}_{3} \mathrm{I}$}

Applying the parameterization of Nightingale et al. (2000), sea water concentrations and wind speed were almost equally important as driving factors for the variations in the $\mathrm{CH}_{3} \mathrm{I}$ sea-to-air flux for the whole cruise region (Fig. 7) based on their similar regional variability (see the scatter in Fig. 8a and similar error bars at the plot that includes all data points in Figure 8b). Diel variability in fluxes could be mainly ascribed to variations in oceanic $\mathrm{CH}_{3} \mathrm{I}$, since they were much higher than the diel variability in wind speed (Fig. 8a, b). Significant correlations of wind speed with sea-to-air fluxes of $\mathrm{CH}_{3} \mathrm{I}$ were only found at two $24 \mathrm{~h}$-station. The high correlation to wind speed at $\mathrm{S} 1$ was caused by the large variability of the generally low speeds in combination with a relatively constant high concentration gradient. Here we note that although the parameterization of Nightingale et al. (2000) is a commonly applied parameterization for $k_{\mathrm{w}}$ in oceanic trace gas emissions, it might not include all factors influencing sea-to-air fluxes. Stability of the atmosphere and the ocean, sea state, bubble transfer, as well as surfactants might influence the transfer across the air-sea interface as well. Some of these factors are included in the TOGA COARE algorithm representing an alternative method for deriving transfer coefficients, which involves an additional set of meteorological parameters such as air temperature and specific humidity profiles, solar irradiance, downwelling longwave irradiance, and precipitation (Fairall et al., 2003).

Our mean $\left(10^{\text {th }}-90^{\text {th }}\right.$ percentile) fluxes of 268 (64-550) in the open ocean and $246(42-523) \mathrm{pmol} \mathrm{m}^{-2} \mathrm{~h}^{-1}$ in the coastal region are 7.5 and 8.7 lower than the fluxes of Jones et al. (2010) of 2021 (417-4046) and 2154 (3214096) $\mathrm{pmol} \mathrm{m}^{-2} \mathrm{~h}^{-1}$. Although the spatial resolution of the measurements by Jones et al. (2010) in the same region was higher than during DRIVE, the difference in emission strength can be mainly explained by their large sea water concentrations and very low atmospheric mixing ratios compared to our study. The fluxes reported here were 3.8 times lower than fluxes reported by Richter and Wallace (2004) $\left(958.3 \pm 750.0 \mathrm{pmol} \mathrm{m}^{-2} \mathrm{~h}^{-1}\right)$ using a similar flux parameterization which are a result of higher oceanic $\mathrm{CH}_{3} \mathrm{I}$ as well.

\subsection{Sea-to-air fluxes of $\mathrm{CHBr}_{3}$ and $\mathrm{CH}_{2} \mathrm{Br}_{2}$}

\subsubsection{Oceanic and atmospheric $\mathrm{CHBr}_{3}$ and $\mathrm{CH}_{2} \mathrm{Br}_{2}$ as drivers of regional and diel variability of the concentration gradient}

The oceanic concentrations of both compounds were generally driving factors for their concentration gradients during DRIVE. Only in the open ocean atmospheric $\mathrm{CHBr}_{3}$ and $\mathrm{CH}_{2} \mathrm{Br}_{2}$ reduced the sea-to-air fluxes significantly (Fig. 6) where the low oceanic concentrations were close to equilibrium with the atmosphere and even led to undersaturation of $\mathrm{CHBr}_{3}$ at S2. The concentration gradient increased towards the Mauritanian upwelling with a much more pronounced increase in oceanic $\mathrm{CHBr}_{3}$ and $\mathrm{CH}_{2} \mathrm{Br}_{2}$ than in the atmosphere. The oceanic and atmospheric concentrations as well as the concentration gradients of both bromocarbons peaked simultaneously at coastal station S5. Open ocean $\mathrm{CHBr}_{3}(1.0$ $\left.3.8 \mathrm{pmol} \mathrm{L}^{-1}\right)$ and $\mathrm{CH}_{2} \mathrm{Br}_{2}\left(1.0-2.2 \mathrm{pmol} \mathrm{L}^{-1}\right)$, increasing towards the coast of Mauritania to $8.1-42.4 \mathrm{pmol} \mathrm{L}^{-1}$ and 

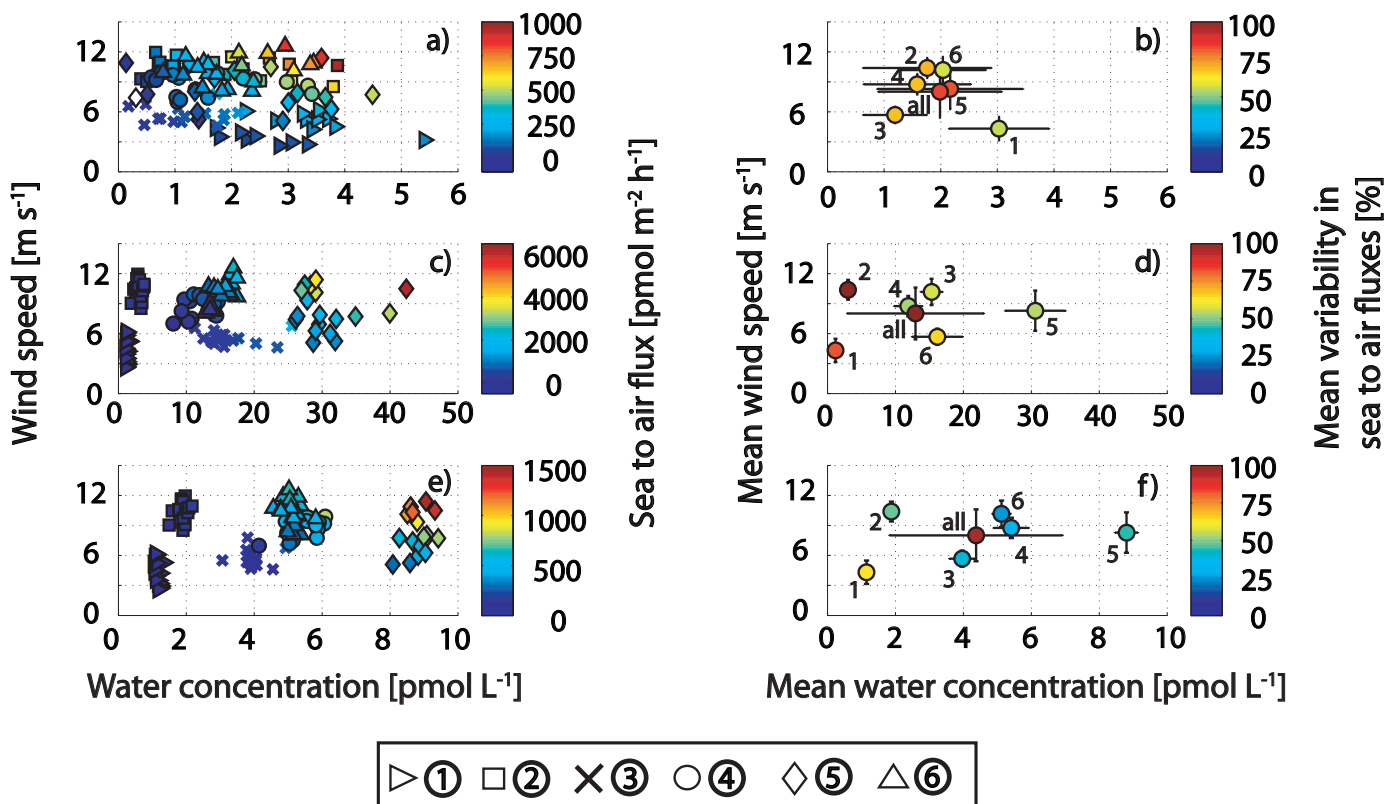

Fig. 8. Left side - wind speed versus $\mathrm{CH}_{3} \mathrm{I}(\mathbf{a}), \mathrm{CHBr}_{3}$ (c) and $\mathrm{CH}_{2} \mathrm{Br}_{2}$ (e) water concentrations. Symbols are filled according to their seato-air flux (see color bars). Right side - mean wind speed versus mean $\mathrm{CH}_{3} \mathrm{I}$ (b), $\mathrm{CHBr}_{3}$ (d) and $\mathrm{CH}_{2} \mathrm{Br}_{2}$ (f) water concentrations with their standard deviations which is expressed in error bars (horizontal for water concentrations and vertical for wind speed) for each diel station (S1-S6) and for all stations together. Symbols are filled with the relative standard deviations of the sea-to-air fluxes (see color bars).

Table 5. Phytoplankton pigments that were found to be significant at $\mathrm{p}<0.05$ and what they are indicative for.

\begin{tabular}{llll}
\hline Pigment & Indicative for & $\mathrm{CHBr}_{3}$ & $\mathrm{CH}_{2} \mathrm{Br}_{2}$ \\
\hline Chlorophyll $b$ & Chlorophytes & $\mathrm{x}$ & $\mathrm{x}$ \\
Chlorophyll $c 3$ & Haptophytes & $\mathrm{x}$ & \\
Fucoxanthin & Diatoms & $\mathrm{x}$ & $\mathrm{x}$ \\
Diatoxanthin & Cyanobacteria & $\mathrm{x}$ & \\
Zeaxanthin & Cryptophytes & & $\mathrm{x}$ \\
$\alpha$-carotene & & $\mathrm{x}$ \\
Alloxanthin & Crazing & $\mathrm{x}$ & \\
Pyrophaephorbide a & Grape & \\
\hline
\end{tabular}

3.1-9.4 $\mathrm{pmol} \mathrm{L}^{-1}$, respectively were in good agreement to earlier studies conducted in the oligotrophic tropical and subtropical Atlantic. Class and Ballschmiter (1988) reported 3.2-23.7 $\mathrm{pmol} \mathrm{L}^{-1}$ for $\mathrm{CHBr}_{3}$ and $1.7-5.8 \mathrm{pmol} \mathrm{L}^{-1}$ for $\mathrm{CH}_{2} \mathrm{Br}_{2}$ in March, Schall et al. (1997) found 3.2-8.0 for $\mathrm{CHBr}_{3}$ and $1.0-1.8 \mathrm{pmol} \mathrm{L}^{-1}$ for $\mathrm{CH}_{2} \mathrm{Br}_{2}$ in boreal wintertime, while Carpenter et al. (2009) published values from the same season as DRIVE of 2.1-43.6 for $\mathrm{CHBr}_{3}$ and $0.7-$ $8.7 \mathrm{pmol} \mathrm{L}-1$ for $\mathrm{CH}_{2} \mathrm{Br}_{2}$ with the highest values in the Mauritanian upwelling and close to the coast. In contrast to oceanic $\mathrm{CH}_{3} \mathrm{I}$ during DRIVE, oceanic $\mathrm{CHBr}_{3}$ and $\mathrm{CH}_{2} \mathrm{Br}_{2}$ was elevated in the biological active regions and correlated with phytoplankton pigments.

Possible biological sources during DRIVE were identified by using pigments indicative for various phytoplank- ton groups which were investigated with MLR more thoroughly. However it should be noted that, for example, fucoxanthin, which mainly occurs in diatoms, is also present in other phytoplankton groups to a certain extent (Jeffrey and Vesk, 1997). Production of halocarbons and the occurrence of the phytoplankton pigments may also take place on different time scales, which may obscure or stimulate a correlation. $\mathrm{CHBr}_{3}$ and $\mathrm{CH}_{2} \mathrm{Br}_{2}$ showed a relationship to Chlorophytes and Diatoms while $\mathrm{CHBr}_{3}$ also correlated significantly with Cyanobacteria and $\mathrm{CH}_{2} \mathrm{Br}_{2}$ with Cryptophytes (Tables 3, 5). Similar biological sources for both bromocarbons are in agreement to previous studies (Manley et al., 1992; Tokarczyk and Moore, 1994). The regional distribution of Chlorophytes and $\mathrm{CHBr}_{3}$ and $\mathrm{CH}_{2} \mathrm{Br}_{2}$ were in best agreement to each other. Diatoms, although they were the dominant species in the Mauritanian upwelling and have been shown to produce halocarbons in the laboratory (Moore et al., 1996), appeared not as major contributors to bromocarbons which is in agreement to Quack et al. (2007b). Additionally, pyrophaeophorbide $a$ was shown to be significant for the $\mathrm{CHBr}_{3}$ distribution. This chlorophyll degradation product is specific for grazing which could lead to release of bromocarbons (Nightingale et al., 1995) produced within the algae (Moore et al., 1996). The correlations with phytoplankton pigments indicate a potential biological production of $\mathrm{CHBr}_{3}$ and $\mathrm{CH}_{2} \mathrm{Br}_{2}$, which is also supported by their regional distribution. However, these correlations can neither resolve the rates of production and loss processes of bromocarbons in the ocean, nor their temporal and spatial distribution. Thus, 
the correlations found during DRIVE only represent indicators to possible source organisms.

Diel variability in the open ocean for both bromocarbons was very low and increased towards the coast. No relationship of halocarbons to either light, SST or salinity was found during $24 \mathrm{~h}$. Elevated $\mathrm{CHBr}_{3}$ and $\mathrm{CH}_{2} \mathrm{Br}_{2}$ were usually observed during evening (S3, S4 and S6) and night hours (S5). In contrast, many laboratory and field studies with both macroalgae and phytoplankton have shown maxima of $\mathrm{CHBr}_{3}$ and $\mathrm{CH}_{2} \mathrm{Br}_{2}$ during the day which was attributed to light induced oxidative stress on the organisms (Ekdahl et al., 1998; Carpenter et al., 2000; Abrahamsson et al., 2004). Bromocarbon production from phytoplankton is still poorly characterized. Elevated bromocarbon production during night may indicate formation during respiration in contrast to light linked production during photosynthesis (Ekdahl et al., 1998; Abrahamsson et al., 2004) or other stress factors such as grazing. Alternatively, $\mathrm{CHBr}_{3}$ and $\mathrm{CH}_{2} \mathrm{Br}_{2}$ could also be stored in the algal cells during light production and released later during the night time (Ekdahl et al., 1998) which would obscure a correlation to light in the field.

In conclusion, the regional variability of the concentration gradients of both bromocarbons was probably a result of the regional differences in primary production supported by their relationship to SST and phytoplankton pigment data (Sect. 4.2.3).

\subsubsection{The relative influence of concentration gradient and wind speed on sea-to-air fluxes of $\mathrm{CHBr}_{3}$ and $\mathrm{CH}_{2} \mathrm{Br}_{2}$}

The regional distribution of sea-to-air fluxes of both bromocarbons was strongly determined by the most likely biologically produced oceanic $\mathrm{CHBr}_{3}$ and $\mathrm{CH}_{2} \mathrm{Br}_{2}$. The regional variability in oceanic bromocarbons was much larger than the regional variations in wind speed (Fig. 8c-f). However, within individual stations, the variability in oceanic $\mathrm{CHBr}_{3}$ and $\mathrm{CH}_{2} \mathrm{Br}_{2}$ was mostly lower than the variations in wind speed. At the open ocean stations, only very low oceanic bromocarbons were measured leading to very low concentration gradients and thus to very low sea-to-air fluxes, since the wind speed did not have a large impact on the variability of sea-to-air fluxes. With increasing oceanic $\mathrm{CHBr}_{3}$ and $\mathrm{CH}_{2} \mathrm{Br}_{2}$ concentrations, the diel impact of changes in wind speed on the sea-to-air flux variability increased which is expressed in high correlation coefficients (Table 4, Fig. 8c, e). This effect was most pronounced for $\mathrm{CH}_{2} \mathrm{Br}_{2}$ which showed the lowest diel concentration variability of all three halocarbons (see the scatter in Fig. 8e). The influences of wind speed and concentration gradient on the emissions of bromocarbons are discussed based on the parameterization of Nightingale et al. (2000), which may not include all control factors similarly to our discussions concerning $\mathrm{CH}_{3} \mathrm{I}$ emissions (Sect. 5.1.2).
Carpenter et al. (2009) derived 8.9 times higher $\mathrm{CHBr}_{3}$ fluxes in the open ocean and 1.3 times higher in the coastal region of mean (10th-90th percentile) 367 (42-625) and 1483 (421-3504) $\mathrm{pmol} \mathrm{m}^{-2} \mathrm{~h}^{-1}$ in comparison to our study with $41(-150-222)$ and $1171(300-2463) \mathrm{pmol} \mathrm{m}^{-2} \mathrm{~h}^{-1}$. Sea-to-air fluxes of $\mathrm{CH}_{2} \mathrm{Br}_{2}$ calculated by Carpenter et al. (2009) were 2.4 times higher in the open ocean and in a similar range in the coastal region with 158 (17-288) and 554 (204-917) $\mathrm{pmol} \mathrm{m}^{-2} \mathrm{~h}^{-1}$ in comparison to 66 (5-155) and 483 (109-809) $\mathrm{pmol} \mathrm{m}^{-2} \mathrm{~h}^{-1}$ (this study) analyzing the same season and region although with higher spatial resolution. This resulted from larger concentration gradients due to their lower atmospheric mixing ratios and comparable ambient parameters.

\subsection{Other impact factors on sea-to-air fluxes: MABL height and SST}

Wind speed and concentration gradients are direct factors that influence sea-to-air fluxes. Some more indirect factors that could possibly impact the emissions include SST and the MABL through their intensifying or decreasing effect on the concentration gradient. Possible effects of the changes in SST on the solubility of oceanic halocarbons and therewith their concentration gradients were small during DRIVE compared to the variability in sea water concentrations (Fig. 2).

The MABL height has implications for the atmospheric mixing ratios of halocarbons and their sea-to-air fluxes via the concentration or dilution of atmospheric halocarbons, emitted from the oceans, within a decreasing or increasing MABL height (Fuhlbrügge et al., 2013). In order to understand the possible effect of MABL variations, sea-to-air fluxes of all three halocarbons were calculated with minimum and maximum atmospheric mixing ratios associated with high (S1) and low MABL heights (S5) to cover the range of potential fluxes in the study region (Fig. 9). A different concentration distribution caused by other atmospheric conditions can change the $\mathrm{CHBr}_{3}$ and $\mathrm{CH}_{2} \mathrm{Br}_{2}$ sea-to-air fluxes on average between $19 \%$ (S5) and $4160 \%$ (S1) for $\mathrm{CHBr}_{3}$ and between $7 \%$ (S5) and $1337 \%$ (S1) for $\mathrm{CH}_{2} \mathrm{Br}_{2}$ (see the lower and upper limits in Fig. 9b-c; the shading implicates the potential range). The effect on the $\mathrm{CH}_{3} \mathrm{I}$ fluxes is from $1 \%$ (S1) to $42 \%$ (S4) (Fig. 9a) lower due to its high supersaturation (Fig. 4a). Considering the large MABL height changes occurring within one day above coastal stations, e.g. from 100 to $350 \mathrm{~m}$ at S6, the effect of the entailing varying atmospheric mixing ratios on local emissions has to be taken into account when assessing halocarbon sea-to-air fluxes from coastal upwelling regions. 

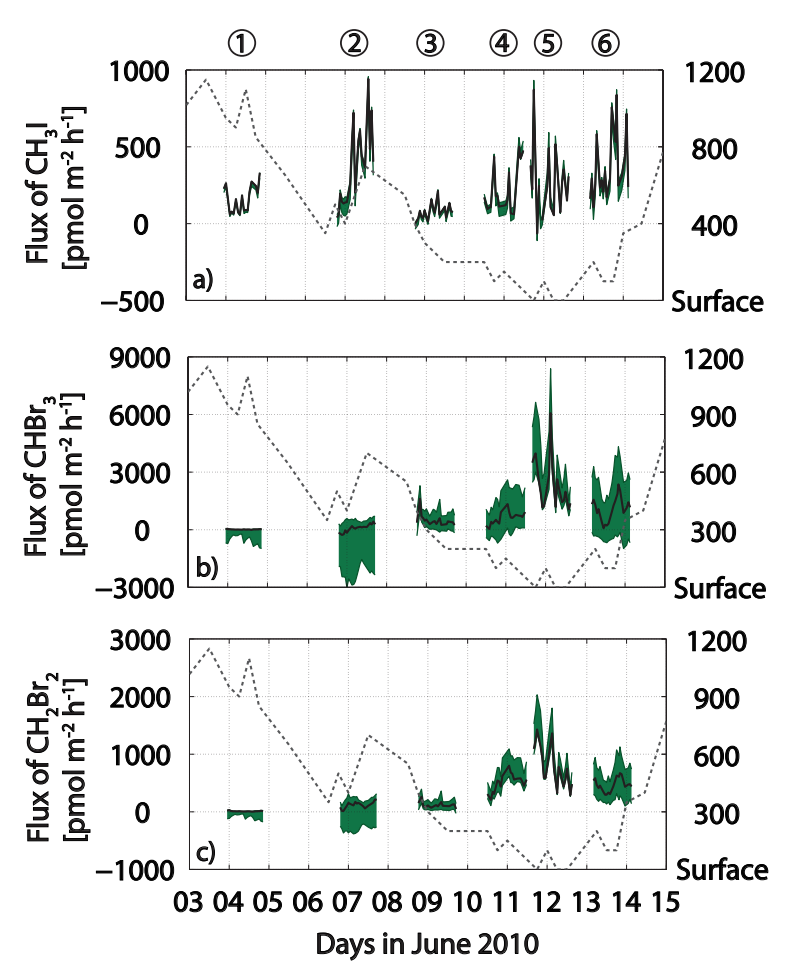

Fig. 9. Sea-to-air fluxes for $\mathrm{CH}_{3} \mathrm{I}\left(\right.$ a), $\mathrm{CHBr}_{3}$ (b) and $\mathrm{CH}_{2} \mathrm{Br}_{2}$ (c) during DRIVE and the MABL height, determined by Fuhlbrügge et al. (2013) as the dashed grey line are shown on the right side. The upper and lower value of potential sea-to-air fluxes assuming the lowest MABL (lower range, 3.0 ppt for $\mathrm{CH}_{3} \mathrm{I}, 3.1 \mathrm{ppt}$ for $\mathrm{CH}_{2} \mathrm{Br}_{2}$ and $8.9 \mathrm{ppt}$ for $\mathrm{CHBr}_{3}$ ) and the highest MABL (upper range, $0.6 \mathrm{ppt}$ for $\mathrm{CH}_{3} \mathrm{I}, 0.9 \mathrm{ppt}$ for $\mathrm{CH}_{2} \mathrm{Br}_{2}$ and $0.5 \mathrm{ppt}$ for $\mathrm{CHBr}_{3}$ ) valid for the whole region are shaded in green.

\subsection{Oceanic influence on atmospheric mixing ratios of $\mathrm{CH}_{3} \mathrm{I}, \mathrm{CHBr}_{3}$ and $\mathrm{CH}_{2} \mathrm{Br}_{2}$}

\subsubsection{The contribution of the oceanic emissions to the atmospheric mixing ratios}

We have shown in the last sections that the sea-to-air fluxes of halocarbons are dominated by the oceanic production and that the sea water concentrations of bromocarbons are increasing towards the coast. In order to understand the importance of sea-to-air fluxes for the atmospheric halocarbon distribution, we calculated their relative contributions to the atmospheric mixing ratios at the individual $24 \mathrm{~h}$-stations. Previous studies assigned the high $\mathrm{CHBr}_{3}$ and $\mathrm{CH}_{2} \mathrm{Br}_{2}$ mixing ratios above the coastal upwellling to air masses originating from the North West African continent (Quack et al., 2007a) and very low atmospheric bromocarbons to air masses from the northern open ocean (Carpenter et al., 2009; Lee et al., 2010). Air masses during coastal station S5 also arrived from the northern open ocean (Fuhlbrügge et al., 2013) which contradicts the hypothesis that high atmospheric halocarbons could only be accounted for by continental sources.

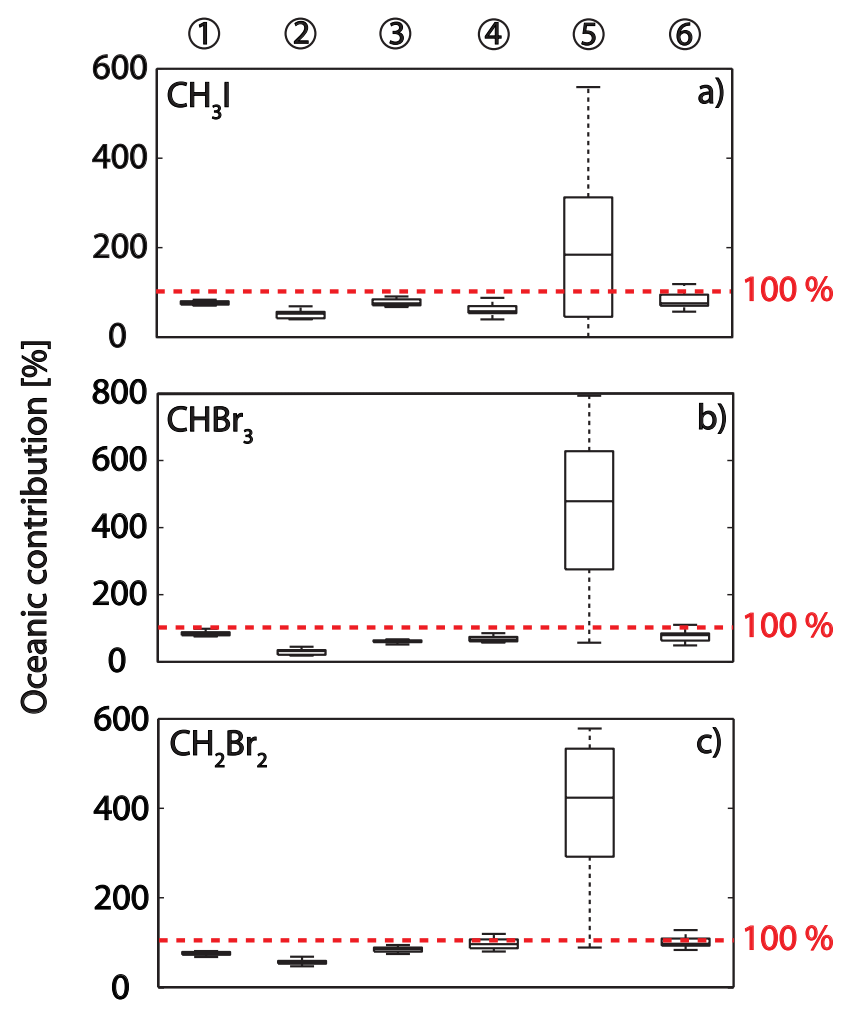

Fig. 10. Oceanic contributions to atmospheric halocarbons assuming a mean distance of $200 \mathrm{~km}$, mean wind speeds, mean sea-to-air fluxes and background mixing ratios for the open ocean $\left(\mathrm{CH}_{3} \mathrm{I}=\right.$ $\left.0.50 \mathrm{ppt}, \mathrm{CHBr}_{3}=0.50 \mathrm{ppt}, \mathrm{CH}_{2} \mathrm{Br}_{2}=0.75 \mathrm{ppt}\right)$ and the coastal region $\left(\mathrm{CH}_{3} \mathrm{I}=0.75 \mathrm{ppt}, \mathrm{CHBr}_{3}=3.00 \mathrm{ppt}, \mathrm{CH}_{2} \mathrm{Br}_{2}=1.80 \mathrm{ppt}\right)$, and the MABL heights determined by Fuhlbrügge et al. (2013) at every measurement point for $\mathrm{CH}_{3} \mathrm{I}(\mathbf{a})$, for $\mathrm{CHBr}_{3}$ (b) and for $\mathrm{CH}_{2} \mathrm{Br}_{2}$ (c), outliers are excluded. The red dashed line marks $100 \%$ in every plot.

For our calculations, we apply a fetch of $200 \mathrm{~km}$ (the mean distance between the diel stations), sea-to-air fluxes from Sects. 4.1.5 and 4.2.6, according wind speeds and MABL heights (Table 1). The sea-to-air fluxes and the height of the MABL have numerically the same influence on atmospheric mixing ratios since bromocarbons in the atmosphere are within the calculations a product of both. Applying a fetch of $200 \mathrm{~km}$, the air mass travels approximately $7 \mathrm{~h}$ until it arrives at the diel stations. Open ocean background values for $\mathrm{S} 1$ and $\mathrm{S} 2$ were set to $0.50 \mathrm{ppt}$ for $\mathrm{CH}_{3} \mathrm{I}$ and $\mathrm{CHBr}_{3}$, and $0.75 \mathrm{ppt}$ for $\mathrm{CH}_{2} \mathrm{Br}_{2}$, while higher background values of $0.75 \mathrm{ppt}$ for $\mathrm{CH}_{3} \mathrm{I}, 1.80 \mathrm{ppt}$ for $\mathrm{CH}_{2} \mathrm{Br}_{2}$ and $3.00 \mathrm{ppt}$ for $\mathrm{CHBr}_{3}$ were assigned to coastal stations S3-S6. We did not include the tropical atmospheric lifetimes of the three halocarbons $\left(7,24,123\right.$ days for $\mathrm{CH}_{3} \mathrm{I}, \mathrm{CHBr}_{3}, \mathrm{CH}_{2} \mathrm{Br}_{2}$; Montzka and Reimann, 2011) since the degradation during the short-term box-calculation has no substantial influence on the results. The oceanic emissions are nearly sufficient to explain most of the atmospheric halocarbons (Fig. 10a-c). Oceanic halocarbon contributions at S1-S6 (except for S5) 

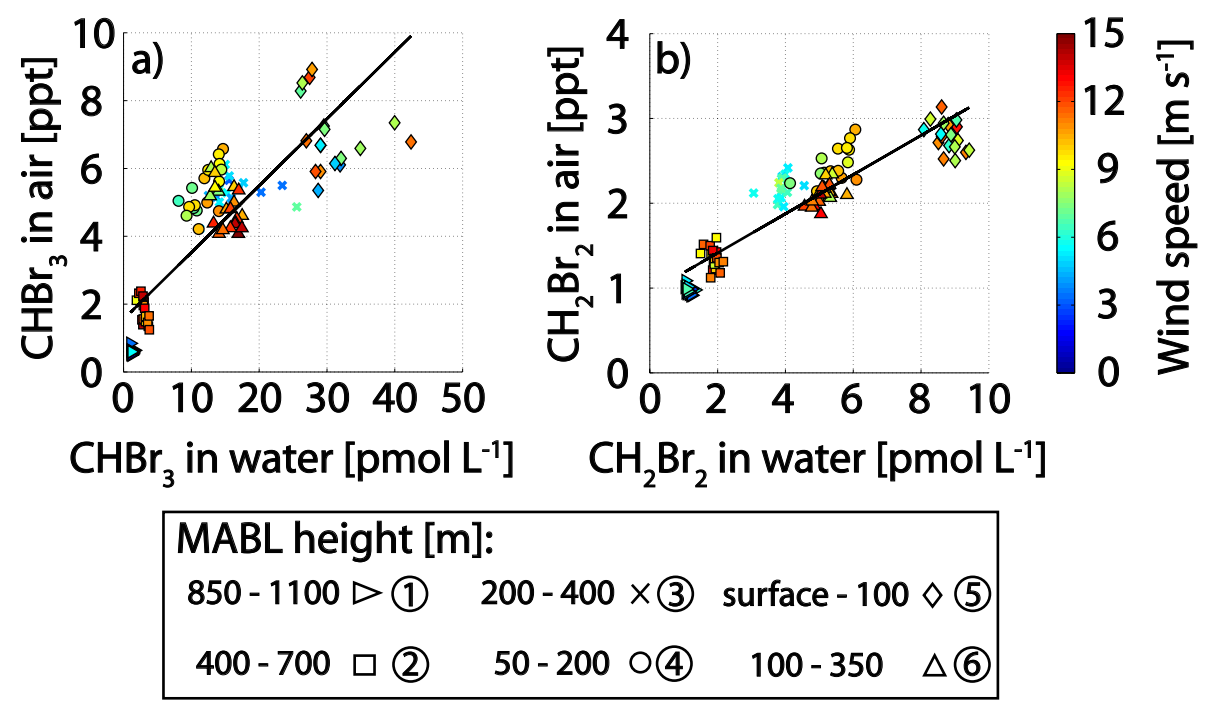

Fig. 11. Correlations of oceanic versus atmospheric halocarbons $\left(\mathrm{CHBr}_{3}\right.$ in a and $\mathrm{CH}_{2} \mathrm{Br}_{2}$ in $\left.\mathbf{b}\right)$ filled with wind speed (see color coding). The black line indicates the regression line for the whole cruise. For the individual correlation coefficients see Table 6.

ranged from 39 to $135 \%$ for $\mathrm{CH}_{3} \mathrm{I}$, between 18 and $126 \%$ for $\mathrm{CHBr}_{3}$ and from 47 to $148 \%$ for $\mathrm{CH}_{2} \mathrm{Br}_{2}$ with generally lowest contributions at $\mathrm{S} 2\left(40-69 \%\right.$ for $\mathrm{CH}_{3} \mathrm{I}, 18-45 \%$ for $\mathrm{CHBr}_{3}$ and $47-68 \%$ for $\left.\mathrm{CH}_{2} \mathrm{Br}_{2}\right)$. At S5, the emissions from the assumed $200 \mathrm{~km}$ fetch contributed $560\left(\mathrm{CH}_{3} \mathrm{I}\right)-800 \%$ $\left(\mathrm{CHBr}_{3}\right)$ to the observed mixing ratios. At this station high oceanic and atmospheric $\mathrm{CHBr}_{3}$ and $\mathrm{CH}_{2} \mathrm{Br}_{2}$ coincided with very low MABL heights. These results suggest that (1) atmospheric mixing ratios over the open ocean S1-S2 are derived from regional emissions and distant sources, (2) the source strength in combination with the observed MABL height can nearly maintain the medium range of atmospheric mixing ratios found at S3, S4, and S6, and (3) the high sea-to-air fluxes and low MABL heights leading to the highly elevated atmospheric mixing ratios at S5 are a very local phenomenon, constrained to the boundaries of this station. The large overestimation of mixing ratios within the box model is then a result of the extrapolation of the high sea-to-air fluxes to the fetch of $200 \mathrm{~km}$. Vertical transport has been neglected in this simple model approach, which likely introduces only small errors since the top of the MABL was very stable and isolated above all coastal stations (Fuhlbrügge et al., 2013).

While the Mauritanian upwelling has been identified to contribute to the high atmospheric abundances of all halocarbons in the region, the elevated and highly variable atmospheric mixing ratios of $\mathrm{CHBr}_{3}$ and $\mathrm{CH}_{2} \mathrm{Br}_{2}$ at Cape Verde can be attributed to local sources. O'Brien et al. (2009) suggested high atmospheric halocarbons at CVAO originating from the coastal region off Mauritania. However, back trajectory analysis revealed air masses at CVAO originating from the open ocean during our investigation (Fuhlbrügge et al., 2013). This together with the considerably lower atmospheric mixing ratios measured at the open ocean sta- tions $\left(0.5-2.4 \mathrm{ppt}\right.$ for $\mathrm{CHBr}_{3}$ and $0.9-1.6 \mathrm{ppt}$ for $\left.\mathrm{CH}_{2} \mathrm{Br}_{2}\right)$ and around the upwelling contradicts upwelling originated halocarbons at Cape Verde during DRIVE. In addition, $\mathrm{CHBr}_{3}$ reached its highest value of the whole campaign at CVAO. Hence, the high and variable atmospheric $\mathrm{CHBr}_{3}$ and $\mathrm{CH}_{2} \mathrm{Br}_{2}$ at Cape Verde in combination with comparably variable wind speeds suggest local coastal sources for both compounds.

\subsubsection{Correlations between oceanic and atmospheric $\mathrm{CHBr}_{3}$ and $\mathrm{CH}_{2} \mathrm{Br}_{2}$}

In contrast to the observations presented in Quack et al. (2007a) and Carpenter et al. (2009), atmospheric $\mathrm{CHBr}_{3}$ and $\mathrm{CH}_{2} \mathrm{Br}_{2}$ followed the same regional distribution as their oceanic counterparts. Water concentrations and atmospheric mixing ratios of $\mathrm{CHBr}_{3}\left(R^{2}=0.74\right)$ and $\mathrm{CH}_{2} \mathrm{Br}_{2}\left(R^{2}=0.85\right)$ correlated regionally very well during DRIVE (Fig. 11a-b) which has not been observed during the other cruises. This is likely caused by a combination of the stable and isolated marine boundary layer observed over the upwelling, the coinciding high productivity and concentration of the bromocarbons in the upwelling, and the combined effects of airsea exchange as slowest process (over a considerable fetch) and advection as the fastest (diluting with background air), both influencing the atmospheric signals. We assume biological production of bromocarbons and mixing within the water column also as rapid processes (Ekdahl et al., 1998). Correlations between atmospheric mixing ratios and oceanic concentrations within the individual 24h-stations were only significant at open ocean station $\mathrm{S} 2$ for $\mathrm{CHBr}_{3}$ and at coastal stations S4 and S6 for both compounds (Table 6). A diel anticorrelation of atmospheric mixing ratios with water concentrations was also observed at several diel stations (S1, S2, S5, 
Table 6. Correlation coefficients $R^{2}$ and number of data points $\mathrm{n}$ of oceanic versus atmospheric bromocarbons for the whole cruise and each individual station. Bold numbers indicate significant correlations with $\mathrm{p}<0.05$. Italic numbers mark negative correlations.

\begin{tabular}{|c|c|c|c|c|c|c|c|}
\hline & Whole cruise & $\begin{array}{l}\mathrm{S} 1 \\
\left(17.6^{\circ} \mathrm{N} \text { and }\right. \\
\left.24.3^{\circ} \mathrm{W}\right)\end{array}$ & $\begin{array}{l}\mathrm{S} 2 \\
\left(18.0^{\circ} \mathrm{N} \text { and }\right. \\
\left.21.0^{\circ} \mathrm{W}\right)\end{array}$ & $\begin{array}{l}\mathrm{S} 3 \\
\left(18.0^{\circ} \mathrm{N} \text { and }\right. \\
\left.18.0^{\circ} \mathrm{W}\right)\end{array}$ & $\begin{array}{l}\mathrm{S} 4 \\
\left(18.5^{\circ} \mathrm{N} \text { and }\right. \\
\left.16.5^{\circ} \mathrm{W}\right)\end{array}$ & $\begin{array}{l}\text { S5 } \\
\left(19.0^{\circ} \mathrm{N} \text { and }\right. \\
\left.16.6^{\circ} \mathrm{W}\right)\end{array}$ & $\begin{array}{l}\mathrm{S} 6 \\
\left(20.0^{\circ} \mathrm{N} \text { and }\right. \\
\left.17.3^{\circ} \mathrm{W}\right)\end{array}$ \\
\hline $\mathrm{CHBr}_{3}$ & 0.74 & 0.01 & 0.52 & 0.01 & 0.45 & 0.05 & 0.20 \\
\hline $\mathrm{CH}_{2} \mathrm{Br}_{2}$ & 0.85 & 0.19 & 0.09 & 0.01 & 0.40 & 0.18 & 0.28 \\
\hline$n$ & 109 & 18 & 19 & 17 & 17 & 18 & 20 \\
\hline
\end{tabular}

and S6). An explanation for this observation (see Table 6) between the atmospheric and oceanic concentrations on a diel scale is still lacking, since neither wind direction, including land-sea breeze circulation (Fuhlbrügge et al., 2013), nor MABL height variations led to clear correlations.

Positive and negative deviations from the overall good regional correlation of sea water concentrations and atmospheric mixing ratios could also be observed at the individual stations. Atmospheric concentrations can increase with wind speed due to increasing sea-to-air fluxes, while elevated wind speeds also dilute local emissions with background air and vice versa. Thus, low wind speeds in the open ocean led to lower atmospheric mixing ratios at $\mathrm{S} 1$ while the higher wind speeds at $\mathrm{S} 2$ triggered average mixing ratios (Fig. 11). This may not only be a result of increasing sea-to-air flux and fetch, but may also be partly a result of the reduction of the MABL height. While coastal stations S3, S4 and S6 have similar mean $\mathrm{CHBr}_{3}$ surface water concentrations, S6 showed the largest sea-to-air fluxes of these three stations due to the largest prevailing wind speeds (see Fig. 5), but on average relatively low atmospheric mixing ratios (Fig. 11a, b). We interpret this as intense transport phenomenon and possible dilution of the large sea-to-air fluxes with background air masses due to intensifying winds and increasing MABL height. Although atmospheric mixing ratios for $\mathrm{CHBr}_{3}$ and $\mathrm{CH}_{2} \mathrm{Br}_{2}$ were highest at $\mathrm{S} 5$, they are on average much lower as could be expected from the overall regional correlation and the large sea water concentrations (see the data points below the correlation line in Fig. 11a, b in contrast to most of the data points from other stations that are above the line). We hypothesize regional mixing with background air masses as cause for the lower than average correlation of sea surface $\mathrm{CHBr}_{3}$ and $\mathrm{CH}_{2} \mathrm{Br}_{2}$ and atmospheric bromocarbons, which supports that the high atmospheric mixing ratios at $\mathrm{S} 5$, the high sea-to-air fluxes, and low MABL height are very local phenomena. The good overall correlation between atmospheric and oceanic bromocarbons shows the dominance of sea water production for the atmosphere. The co-correlation of increased productivity and production of bromocarbons during upwelling of cold and nutrient rich water and the high atmospheric mixing ratios in a low and stable MABL over the low sea surface temperature of the upwelled water (Fuhlbrügge et al., 2013) can be explained within the known concepts of wind driven air-sea exchange, advection and MABL variations on a regional scale.

\section{Summary and conclusions}

We have discussed the temporal and spatial influence of biological productivity, wind speed, MABL height and SST on oceanic emissions and atmospheric mixing ratios of halocarbons in the tropical North East Atlantic.

During DRIVE, oceanic $\mathrm{CH}_{3} \mathrm{I}$ neither showed a relationship to phytoplankton pigments nor to cyanobacteria, and its distribution appeared mainly as a result of abiotic or indirect biological formation which seemed to be the main driver of the $\mathrm{CH}_{3} \mathrm{I}$ concentration gradient between sea water and air. On a regional scale, neither wind speed nor oceanic $\mathrm{CH}_{3} \mathrm{I}$ were dominating the sea-to-air flux, while diel variations in emissions were a result of varying oceanic $\mathrm{CH}_{3} \mathrm{I}$ concentrations almost throughout the whole cruise. On the contrary, the oceanic distribution of $\mathrm{CHBr}_{3}$ and $\mathrm{CH}_{2} \mathrm{Br}_{2}$ and their emissions correlated with phytoplankton pigments which implies a biological source, albeit with no clear diurnal cycles unlike observed in previous studies. The variability in wind speed gained increasing impact on the diel bromocarbon emissions with decreasing distance to the coast, because the diel variability in oceanic $\mathrm{CHBr}_{3}$ and even more pronounced in oceanic $\mathrm{CH}_{2} \mathrm{Br}_{2}$ was low in comparison to large diel wind speed variations.

MABL height was identified as an additional factor impacting oceanic emissions of halocarbons in the upwelling through its influence on atmospheric halocarbon abundances. Sea-to-air fluxes of $\mathrm{CH}_{3} \mathrm{I}$ were hardly influenced by the varying MABL due to its high supersaturation in sea surface water. The sea-to-air fluxes of $\mathrm{CHBr}_{3}$ and $\mathrm{CH}_{2} \mathrm{Br}_{2}$ however were substantially influenced by atmospheric conditions High atmospheric $\mathrm{CH}_{3} \mathrm{I}, \mathrm{CHBr}_{3}$ and $\mathrm{CH}_{2} \mathrm{Br}_{2}$ mixing ratios at a coastal site on the Cape Verde islands (CVAO) could be attributed to local coastal sources. Regional oceanic bromocarbon emissions from the upwelling, probably driven by biological production, could in combination with varying and low MABL heights and air mass transport explain most of the observed atmospheric halocarbons, contrasting previous hypotheses regarding additional continental bromo- 
carbon sources above the upwelling. As a result, the atmospheric bromocarbons showed significant and high overall correlations with the oceanic concentrations, which is caused by the coincidence of oceanic production in upwelled water and low and stable MABLs over the cold upwelled water. We therefore hypothesize that low MABL heights and high seato-air fluxes coinciding with high atmospheric mixing ratios could be a common feature in coastal upwelling systems (this study; Fuhlbrügge et al., 2013).

The temporal and spatial development of biological production, wind speed, SST and changes in atmospheric mixing ratios with MABL height will influence the future seato-air fluxes and their corresponding atmospheric mixing ratios, as well as their contribution to atmospheric chemical processes. Surface air and water temperature could play a crucial role in the future development of wind speed via the potentially increased land-sea pressure gradients. A potential future increase of SST in the tropical oligotrophic Atlantic (Hoerling et al., 2001) could lead to enhanced oceanic production of $\mathrm{CH}_{3} \mathrm{I}$ (Richter, 2004) and in combination with reduced solubility to elevated emissions of $\mathrm{CH}_{3} \mathrm{I}$. An elevation of atmospheric $\mathrm{CH}_{3} \mathrm{I}$ with increasing SST and accompanying physical-biological phenomena on a decadal scale has already been shown by Yokouchi et al. (2012) in the tropical and temperate Pacific region. At the same time, the enhancement of eastern boundary upwelling systems accompanied by increasing primary production (Lachkar and Gruber, 2012) could result in higher production of oceanic bromocarbons. Combined with elevated wind speeds (Bakun, 1990), increased emissions of brominated compounds would be the consequence. Hence, the relevance of the tropical upwelling systems with respect to halocarbon emissions will likely increase and the influence of the diel and regional drivers on the emissions may be intensified. To better understand the current and future roles of halocarbon emissions from marine upwelling regions on global ozone changes and atmospheric chemistry, it is important to continue to better quantify the relative roles and interactions of oceanic halocarbon production, wind speed and MABL height, SST and seasonal variations, as well as other relevant forcings in oceanic upwelling regions around the global ocean.

Acknowledgements. The authors would like to thank the chief scientist of the cruise P399/2 Prof Dr Hermann W. Bange, as well as the captain and the crew of the RV Poseidon during P399/2 for all their help and support. We are also very grateful to Karen Stange and Gert Petrick for their technical support before and during the campaign. We would like to acknowledge Carolin Löscher for her help with water sampling for pigment analysis and Bettina Taylor for analysis of the flow cytometry samples. The authors thank Christian Müller and Julian Kinzel for their assistance with air sampling at CVAO. We thank Xiaorong Zhu and Leslie Pope for technical assistance in the air canister analyses. Furthermore, we would like to thank Christa Marandino and Susann Tegtmeier for their helpful input. We acknowledge the National Centre for Atmospheric Science (NCAS) for providing the Cape Verde Atmospheric Observatory wind speed data. Additionally, the authors would like to acknowledge NASA for providing satellite MODIS-Aqua data. We thank the anonymous reviewers for very helpful input and corrections. This work was part of the German research project SOPRAN II (grant no. FKZ 03F0611A) funded by the Bundesministerium für Bildung und Forschung (BMBF), and was also supported by the EU project SHIVA (grant no. FP7-ENV2007-1-226224), as well as NASA UARP Grant NNX09AJ25G.

The service charges for this open access publication have been covered by a Research Centre of the Helmholtz Association.

Edited by: W. T. Sturges

\section{References}

Abrahamsson, K., Lorén, A., Wulff, A., and Wangberg, S. A.: Air-sea exchange of halocarbons: The influence of diurnal and regional variations and distribution of pigments, Deep-Sea Res. Part II-Top. Stud. Oceanogr., 51, 2789-2805, doi:10.1016/j.dsr2.2004.09.005, 2004.

Amachi, S., Kamagata, Y., Kanagawa, T., and Muramatsu, Y.: Bacteria mediate methylation of iodine in marine and terrestrial environments, Appl. Environ. Microbiol., 67, 2718-2722, doi:10.1128/aem.67.6.2718-2722.2001, 2001.

Aschmann, J., Sinnhuber, B. M., Chipperfield, M. P., and Hossaini, R.: Impact of deep convection and dehydration on bromine loading in the upper troposphere and lower stratosphere, Atmos. Chem. Phys., 11, 2671-2687, doi:10.5194/acp-11-26712011, 2011.

Bakun, A.: Global climate change and intensification of coastal ocean upwelling, Science, 247, 198-201, doi:10.1126/science.247.4939.198, 1990.

Bange, H. W., Atlas, E. L., Bahlmann, E., Baker, A. R., Bracher, A., Cianca, A., Dengler, M., Fuhlbrügge, S., Großmann, K., Hepach, H., Lavric, J., Löscher, C., Krüger, K., Orlikowska, A., Peeken, I., Quack, B., Schafstall, J., Steinhoff, T., Williams, J., and Wittke, F.: Fs poseidon fahrtbericht/cruise report p399-2\&3, Leibniz-Institut für Meereswissenschaften IFM-GEOMAR, Kiel, 74, 2011.

Bell, N., Hsu, L., Jacob, D. J., Schultz, M. G., Blake, D. R., Butler, J. H., King, D. B., Lobert, J. M., and Maier-Reimer, E.: Methyl iodide: Atmospheric budget and use as a tracer of marine convection in global models, J. Geophys. Res.-Atmos., 107, 4340, doi:10.1029/2001jd001151, 2002.

Carpenter, L. J. and Liss, P. S.: On temperate sources of bromoform and other reactive organic bromine gases, J. Geophys. Res.Atmos., 105, 20539-20547, 2000.

Carpenter, L. J., Malin, G., Liss, P. S., and Kupper, F. C.: Novel biogenic iodine-containing trihalomethanes and other short-lived halocarbons in the coastal east atlantic, Glob. Biogeochem. Cy., 14, 1191-1204, 2000.

Carpenter, L. J., Jones, C. E., Dunk, R. M., Hornsby, K. E., and Woeltjen, J.: Air-sea fluxes of biogenic bromine from the tropical and north atlantic ocean, Atmos. Chem. Phys., 9, 1805-1816, doi:10.5194/acp-9-1805-2009, 2009. 
Class, T., and Ballschmiter, K.: Chemistry of organic traces in air viii: Sources and distribution of brom- and bromochloromethanes in marine air and surfacewater of the atlantic ocean, J. Atmos. Chem., 6, 35-46, 1988.

Ekdahl, A., Pedersén, M., and Abrahamsson, K.: A study of the diurnal variation of biogenic volatile halocarbons, Mar. Chem., 63, 1-8, 1998.

Fairall, C. W., Bradley, E. F., Hare, J. E., Grachev, A. A., and Edson, J. B.: Bulk parameterization of air-sea fluxes: Updates and verification for the coare algorithm, J. Clim., 16, 571591, doi:10.1175/1520-0442(2003)016<0571:bpoasf >,2.0.co;2, 2003.

Fedoseev, A.: Geostrophic circulation of surface waters on the shelf of north-west africa, Rapp. Proc. Verb. Reun. Cons. Inst. Expl. Mer., 159, 32-37, 1970.

Fuhlbrügge, S., Krüger, K., Quack, B., Atlas, E. L., Hepach, H., and Ziska, F.: Impact of the marine atmospheric boundary layer on vsls abundances in the eastern tropical and subtropical north atlantic ocean, Atmos. Chem. Phys., 13, 6345-6357, doi:10.5194/acp-13-6345-2013, 2013.

Fuse, H., Inoue, H., Murakami, K., Takimura, O., and Yamaoka, Y.: Production of free and organic iodine by roseovarius spp, FEMS Microbiology Letters, 229, 189-194, doi:10.1016/s03781097(03)00839-5, 2003

Hagen, E.: Northwest african upwelling scenario, Oceanol. Acta, 24, S113-S128, 2001.

Happell, J. D. and Wallace, D. W. R.: Methyl iodide in the greenland/norwegian seas and the tropical atlantic ocean: Evidence for photochemical production, Geophys. Res. Lett., 23, 2105-2108, doi:10.1029/96gl01764, 1996.

Hoerling, M. P., Hurrell, J. W., and Xu, T. Y.: Tropical origins for recent north atlantic climate change, Science, 292, 90-92, doi:10.1126/science.1058582, 2001

Hossaini, R., Chipperfield, M. P., Monge-Sanz, B. M., Richards, N. A. D., Atlas, E., and Blake, D. R.: Bromoform and dibromomethane in the tropics: A 3-d model study of chemistry and transport, Atmos. Chem. Phys., 10, 719-735, doi:10.5194/acp10-719-2010, 2010.

Hossaini, R., Chipperfield, M. P., Feng, W., Breider, T. J., Atlas, E., Montzka, S. A., Miller, B. R., Moore, F., and Elkins, J.: The contribution of natural and anthropogenic very short-lived species to stratospheric bromine, Atmos. Chem. Phys., 12, 371380, doi:10.5194/acp-12-371-2012, 2012a.

Hossaini, R., Chipperfield, M. P., Dhomse, S., Ordonez, C., Saiz-Lopez, A., Abraham, N. L., Archibald, A., Braesicke, P., Telford, P., Warwick, N., Yang, X., and Pyle, J.: Modelling future changes to the stratospheric source gas injection of biogenic bromocarbons, Geophys. Res. Lett., 39, L20813, doi:10.1029/2012g1053401, 2012b.

Jeffrey, S. W. and Vesk, M.: Introduction to marine phytoplankton and their pigment signatures, in: Phytoplankton pigments in oceanography: Guideline to modern methods., edited by: Jeffrey, S. W., Mantoura, R. F. C., and Wright, S. W., 10, UNESCO Publishing, Paris, 37-84, 1997.

Jones, C. E., Hornsby, K. E., Sommariva, R., Dunk, R. M., Von Glasow, R., McFiggans, G., and Carpenter, L. J.: Quantifying the contribution of marine organic gases to atmospheric iodine, Geophys. Res. Lett., 37, L18804, doi:10.1029/2010g1043990, 2010.
Lachkar, Z. and Gruber, N.: A comparative study of biological production in eastern boundary upwelling systems using an artificial neural network, Biogeosciences, 9, 293-308, doi:10.5194/bg-9293-2012, 2012

Lai, S. C., Williams, J., Arnold, S. R., Atlas, E. L., Gebhardt, S., and Hoffmann, T.: Iodine containing species in the remote marine boundary layer: A link to oceanic phytoplankton, Geophys. Res. Lett., 38, L20801, doi:10.1029/2011g1049035, 2011.

Laturnus, F.: Marine macroalgae in polar regions as natural sources for volatile organohalogens, Environ. Sci. Pollut. Res., 8, 103108, doi:10.1007/bf02987302, 2001.

Lee, J. D., McFiggans, G., Allan, J. D., Baker, A. R., Ball, S. M., Benton, A. K., Carpenter, L. J., Commane, R., Finley, B. D., Evans, M., Fuentes, E., Furneaux, K., Goddard, A., Good, N., Hamilton, J. F., Heard, D. E., Herrmann, H., Hollingsworth, A., Hopkins, J. R., Ingham, T., Irwin, M., Jones, C. E., Jones, R. L., Keene, W. C., Lawler, M. J., Lehmann, S., Lewis, A. C., Long, M. S., Mahajan, A., Methven, J., Moller, S. J., Muller, K., Muller, T., Niedermeier, N., O'Doherty, S., Oetjen, H., Plane, J. M. C., Pszenny, A. A. P., Read, K. A., Saiz-Lopez, A., Saltzman, E. S., Sander, R., von Glasow, R., Whalley, L., Wiedensohler, A., and Young, D.: Reactive halogens in the marine boundary layer (rhamble): The tropical north atlantic experiments, Atmos. Chem. Phys., 10, 1031-1055, doi:10.5194/acp-10-1031-2010, 2010.

Manley, S. L. and Dastoor, M. N.: Methyl-iodide $\left(\mathrm{CH}_{3} \mathrm{I}\right)$ production by kelp and associated microbes, Mar. Biol., 98, 477-482, 1988

Manley, S. L., Goodwin, K., and North, W. J.: Laboratory production of bromoform, methylene bromide, and methyl-iodide by macroalgae and distribution in nearshore southern california waters, Limnol. Oceanogr., 37, 1652-1659, 1992.

Martino, M., Mills, G. P., Woeltjen, J., and Liss, P. S.: A new source of volatile organoiodine compounds in surface seawater, Geophys. Res. Lett., 36, L01609, doi:10.1029/2008GL036334, 2009.

McGivern, W. S., Sorkhabi, O., Suits, A. G., Derecskei-Kovacs, A., and North, S. W.: Primary and secondary processes in the photodissociation of chbr3, J. Phys. Chem. A, 104, 10085-10091, doi:10.1021/jp0005017, 2000

McGregor, H. V., Dima, M., Fischer, H. W., and Mulitza, S.: Rapid 20th-century increase in coastal upwelling off northwest africa, Science, 315, 637-639, doi:10.1126/science.1134839, 2007.

Minas, H. J., Codispoti, L. A., and Dugdale, R. C.: Nutrients and primary production in the upwelling region off northwest africa, Rapp. Proc. Verb. Reun. Cons. Inst. Expl. Mer., 180, 148-183, 1982.

Mittelstaedt, E.: Large-scale circulation along the coast of northwest africa, Rapp. Proc. Verb. Reun. Cons. Inst. Expl. Mer., 180, 50-57, 1982

Montzka, S. A. and Reimann, S.: Ozone-depleting substances and related chemicals, Chapter 1 in Scientific Assessment of Ozone Depletion: 2010, Global Ozone Research and Monitoring Project, World Meteorological Organization (WMO), Geneva, Report No. 52, 2011

Moore, R. M. and Zafiriou, O. C.: Photochemical production of methyl-iodide in seawater, J. Geophys. Res.-Atmos., 99, 1641516420, doi:10.1029/94jd00786, 1994.

Moore, R. M., Geen, C. E., and Tait, V. K.: Determination of henry law constants for a suite of naturally-occurring halo- 
genated methanes in seawater, Chemosphere, 30, 1183-1191, doi:10.1016/0045-6535(95)00009-w, 1995a.

Moore, R. M., Tokarczyk, R., Tait, V. K., Poulin, M., and Geen, C. E.: Marine phytoplankton as a natural source of volatile organohalogens, in: Naturally-produced organohalogens, edited by: Grimvall, A., and deLeer, E. W. B., Kluwer Academic Publishers, Dordrecht, The Netherlands, 283-294, 1995b.

Moore, R. M., Webb, M., Tokarczyk, R., and Wever, R.: Bromoperoxidase and iodoperoxidase enzymes and production of halogenated methanes in marine diatom cultures, J. Geophys. Res.Oceans, 101, 20899-20908, doi:10.1029/96jc01248, 1996.

Moore, R. M. and Groszko, W.: Methyl iodide distribution in the ocean and fluxes to the atmosphere, J. Geophys. Res.-Oceans, 104, 11163-11171, doi:10.1029/1998jc900073, 1999.

Nightingale, P. D., Malin, G., and Liss, P. S.: Production of chloroform and other low-molecular-weight halocarbons by some species of macroalgae, Limnol. Oceanogr., 40, 680-689, 1995.

Nightingale, P. D., Malin, G., Law, C. S., Watson, A. J., Liss, P. S., Liddicoat, M. I., Boutin, J., and Upstill-Goddard, R. C.: In situ evaluation of air-sea gas exchange parameterizations using novel conservative and volatile tracers, Global Biogeochem. Cy., 14, 373-387, doi:10.1029/1999gb900091, 2000.

O’Brien, L. M., Harris, N. R. P., Robinson, A. D., Gostlow, B., Warwick, N., Yang, X., and Pyle, J. A.: Bromocarbons in the tropical marine boundary layer at the cape verde observatory - measurements and modelling, Atmos. Chem. Phys., 9, 9083-9099, doi:10.5194/acp-9-9083-2009, 2009.

O’Dowd, C. D., Jimenez, J. L., Bahreini, R., Flagan, R. C., Seinfeld, J. H., Hameri, K., Pirjola, L., Kulmala, M., Jennings, S. G., and Hoffmann, T.: Marine aerosol formation from biogenic iodine emissions, Nature, 417, 632-636, doi:10.1038/nature00775, 2002.

Pyle, J. A., Warwick, N., Yang, X., Young, P. J., and Zeng, G.: Climate/chemistry feedbacks and biogenic emissions, Philos. Trans. R. Soc. A-Math. Phys. Eng. Sci., 365, 1727-1740, doi:10.1098/rsta.2007.2041, 2007.

Quack, B. and Wallace, D. W. R.: Air-sea flux of bromoform: Controls, rates, and implications, Glob. Biogeochem. Cy., 17, 1023, doi:10.1029/2002gb001890, 2003.

Quack, B., Atlas, E., Petrick, G., Stroud, V., Schauffler, S., and Wallace, D. W. R.: Oceanic bromoform sources for the tropical atmosphere, Geophys. Res. Lett., 31, L23S05, doi:10.1029/2004g1020597, 2004.

Quack, B., Atlas, E., Petrick, G., and Wallace, D. W. R.: Bromoform and dibromomethane above the mauritanian upwelling: Atmospheric distributions and oceanic emissions, J. Geophys. Res.Atmos., 112, D09312, doi:10.1029/2006jd007614, 2007a.

Quack, B., Peeken, I., Petrick, G., and Nachtigall, K.: Oceanic distribution and sources of bromoform and dibromomethane in the mauritanian upwelling, J. Geophys. Res.-Oceans, 112, C10006, doi:10.1029/2006jc003803, 2007b.

Richter, U.: Factors influencing methyl iodide production in the ocean and its flux to the atmosphere, $\mathrm{PhD}$ thesis, Mathematisch-Naturwissenschaftliche Fakultät der ChristianAlbrechts-Universität zu Kiel, Christian-Albrechts-Universität zu Kiel, Kiel, 117 pp., 2004.

Richter, U. and Wallace, D. W. R.: Production of methyl iodide in the tropical atlantic ocean, Geophys. Res. Lett., 31, L23S03, doi:10.1029/2004g1020779, 2004.
Saiz-Lopez, A., Plane, J. M. C., Baker, A. R., Carpenter, L. J., von Glasow, R., Martin, J. C. G., McFiggans, G., and Saunders, R. W.: Atmospheric chemistry of iodine, Chem. Rev., 112, 17731804, doi:10.1021/cr200029u, 2012.

Salawitch, R. J., Weisenstein, D. K., Kovalenko, L. J., Sioris, C. E., Wennberg, P. O., Chance, K., Ko, M. K. W., and McLinden, C. A.: Sensitivity of ozone to bromine in the lower stratosphere, Geophys. Res. Lett., 32, L05811, doi:10.1029/2004g1021504, 2005.

Schall, C., Heumann, K. G., and Kirst, G. O.: Biogenic volatile organoiodine and organobromine hydrocarbons in the atlantic ocean from 42 degrees $\mathrm{N}$ to 72 degrees S, Fresenius J. Anal. Chem., 359, 298-305, 1997.

Schauffler, S. M., Atlas, E. L., Blake, D. R., Flocke, F., Lueb, R. A., Lee-Taylor, J. M., Stroud, V., and Travnicek, W.: Distributions of brominated organic compounds in the troposphere and lower stratosphere, J. Geophys. Res.-Atmos., 104, 21513-21535, 1999.

Smythe-Wright, D., Boswell, S. M., Breithaupt, P., Davidson, R. D., Dimmer, C. H., and Diaz, L. B. E.: Methyl iodide production in the ocean: Implications for climate change, Glob. Biogeochem. Cy., 20, GB3003, doi:10.1029/2005GB002642, 2006.

Solomon, S., Garcia, R. R., and Ravishankara, A. R.: On the role of iodine in ozone depletion, J. Geophys. Res.-Atmos., 99, 2049120499, doi:10.1029/94JD02028, 1994.

Stemmler, I., Hense, I., Quack, B., and Maier-Reimer, E.: Methyl iodide production in the open ocean, Biogeosciences Discuss., 10, 17549-17595, doi:10.5194/bgd-10-17549-2013, 2013.

Taylor, B. B., Torrecilla, E., Bernhardt, A., Taylor, M. H., Peeken, I., Rottgers, R., Piera, J., and Bracher, A.: Bio-optical provinces in the eastern atlantic ocean and their biogeographical relevance, Biogeosciences, 8, 3609-3629, doi:10.5194/bg-8-36092011, 2011.

Tegtmeier, S., Kruger, K., Quack, B., Atlas, E. L., Pisso, I., Stohl, A., and Yang, X.: Emission and transport of bromocarbons: From the west pacific ocean into the stratosphere, Atmos. Chem. Phys., 12, 10633-10648, doi:10.5194/acp-12-10633-2012, 2012.

Tegtmeier, S., Krüger, K., Quack, B., Atlas, E., Blake, D. R., Boenisch, H., Engel, A., Hepach, H., Hossaini, R., Navarro, M. A., Raimund, S., Sala, S., Shi, Q., and Ziska, F.: The contribution of oceanic methyl iodide to stratospheric iodine, Atmos. Chem. Phys., 13, 11869-11886, doi:10.5194/acp-13-11869-2013, 2013.

Tokarczyk, R. and Moore, R. M.: Production of volatile organohalogens by phytoplankton cultures, Geophys. Res. Lett., 21, 285288, 1994.

Tomczak, M.: The distribution of water masses at the surface as derived from t-s diagram analysis in the cineca area, Rapp. Proc. Verb. Reun. Cons. Inst. Expl. Mer., 180, 48-49, 1982.

Tomczak, M. and Godfrey, J. S.: Regional oceanography: An introduction, 2 ed., Daya Publishing House, Delhi, 2005.

Tran, S., Bonsang, B., Gros, V., Peeken, I., Sarda-Esteve, R., Bernhardt, A., and Belviso, S.: A survey of carbon monoxide and nonmethane hydrocarbons in the arctic ocean during summer 2010 , Biogeosciences, 10, 1909-1935, doi:10.5194/bg-10-1909-2013, 2013.

Tsuchiya, M., Talley, L. D., and McCartney, M. S.: An eastern atlantic section from iceland southward across the equator, DeepSea Res., 39, 1885-1917, doi:10.1016/0198-0149(92)90004-d, 1992. 
Williams, J., Gros, V., Atlas, E., Maciejczyk, K., Batsaikhan, A., Scholer, H. F., Forster, C., Quack, B., Yassaa, N., Sander, R., and Van Dingenen, R.: Possible evidence for a connection between methyl iodide emissions and saharan dust, J. Geophys. Res.-Atmos., 112, D07302, doi:10.1029/2005jd006702, 2007.

Yokouchi, Y., Osada, K., Wada, M., Hasebe, F., Agama, M., Murakami, R., Mukai, H., Nojiri, Y., Inuzuka, Y., Toom-Sauntry, D., and Fraser, P.: Global distribution and seasonal concentration change of methyl iodide in the atmosphere, J. Geophys. Res.Atmos., 113, D18311, doi:10.1029/2008JD009861, 2008.

Yokouchi, Y., Nojiri, Y., Toom-Sauntry, D., Fraser, P., Inuzuka, Y., Tanimoto, H., Nara, H., Murakami, R., and Mukai, H.: Longterm variation of atmospheric methyl iodide and its link to global environmental change, Geophys. Res. Lett., 39, L23805, doi:10.1029/2012GL053695, 2012.
Ziska, F., Quack, B., Abrahamsson, K., Archer, S. D., Atlas, E., Bell, T., Butler, J. H., Carpenter, L. J., Jones, C. E., Harris, N. R. P., Hepach, H., Heumann, K. G., Hughes, C., Kuss, J., Krüger, K., Liss, P., Moore, R. M., Orlikowska, A., Raimund, S., Reeves, C. E., Reifenhäuser, W., Robinson, A. D., Schall, C., Tanhua, T., Tegtmeier, S., Turner, S., Wang, L., Wallace, D., Williams, J., Yamamoto, H., Yvon-Lewis, S., and Yokouchi, Y.: Global sea-toair flux climatology for bromoform, dibromomethane and methyl iodide, Atmos. Chem. Phys., 13, 8915-8934, doi:10.5194/acp13-8915-2013, 2013. 